a Universidade Federal do Ceará, Departamento de Engenharia Química, Campus do Pici, CEP 60455-760, Fortaleza-CE, Brazil. bUniversidade da Integração Internacional da Lusofonia Afro-Brasileira, Instituto de Engenharias e Desenvolvimento Sustentável, Campus das Auroras, CEP 62790970, Redenção-CE, Brazil.

'Universidade da Integração Internacional da Lusofonia Afro-Brasileira, Instituto de Ciências Exatas e da Natureza, Campus da Liberdade, Avenida da Abolição 3, Centro, CEP 62790-000, Redenção-CE, Brazil.

*E-mail: jcs@unilab.edu.br

Recebido: 5 de Outubro de 2020

Aceito: 25 de Fevereiro de 2021

Publicado online: 14 de Abril de 2021

\section{Lipases Immobilized onto Nanomaterials as Biocatalysts in Biodiesel Production: Scientific Context, Challenges, and Opportunities}

\author{
Lipases Imobilizadas em Nanomateriais como Biocatalisadores para a \\ Produção de Biodiesel: Motivações, Desafios e Oportunidades
}

\author{
André L. B. de Oliveira, ${ }^{a}$ Francisco T. T. Cavalcante, ${ }^{a}$ Katerine S. Moreira, ${ }^{a}$ Rodolpho R. C. Monteiro, ${ }^{a}$ \\ Thales G. Rocha, ${ }^{b}$ José E. S. Souza, ${ }^{b}$ Aluísio M. da Fonseca, ${ }^{c}$ Ada A. S. Lopes, ${ }^{b}$ Artemis P. Guimarães, ${ }^{b}$ \\ Rita K. C. de Lima, ${ }^{b}$ Maria C. M. de Souza, José C. S. dos Santos, a, *i(D)
}

Lipases have shown highly relevant biotechnological potential as catalysts in organic synthesis reactions, especially in non-aqueous media, allowing for higher-yielding and more simplified production processes. Incorporating this technology in large scale requires the use of economicallyviable techniques, such as enzyme immobilization onto nanomaterials. The main scientific interest in immobilization protocols is to obtain biocatalysts that present better activity, selectivity, stability, and protein-purification properties, when compared to their free form. In this work, we review some of the properties of lipases and their applications, discuss the problems inherent in free-enzyme protocols, present immobilization techniques as solutions to these issues, and explore some applications of immobilized enzymes. Furthermore, the use of nanomaterials, their properties, and their relevance to the topic are also discussed. This study presents a review of the main advantages and the recent developments in the preparation of lipases immobilized onto nanomaterials as biocatalysts to be used in sustainable routes of biodiesel production.

Keywords: Enzyme immobilization; nanomaterials; sustainable energy; lipases.

\section{Introduction}

The growing interest in biocatalytic processes in recent decades has proved their promising role as alternatives in the development and optimization of industrial technologies for sustainable energy production. ${ }^{1}$ The use of several enzymes as biocatalysts, particularly lipases, ${ }^{2-5}$ is noteworthy, ${ }^{6,7}$ since their participation in the industry market has increased significantly due to numerous advantages over the traditional chemical technology, concerning their specificity, efficiency, and environmental compatibility. ${ }^{8,9}$ Thus, enzymes are potentially attractive replacements and allow for a myriad of applications in different processes, among which is the production of biofuels and other bio-derived products. ${ }^{10,11}$

There are several studies in the literature looking into the production of sustainable energy using enzymatic catalysis to reduce environmental impact. These studies, especially in the realm of biofuels such as biodiesel, show that the use of biocatalysis enables the obtainment of products at higher yields and purity degrees, prevents soap formation, and allows for the use of milder reaction conditions that consequently reduce energy requirements during, and waste generation as a result of, the production process. ${ }^{12-16}$ Other claimed advantages are the possibility of employment of several cheap raw materials and the ease of glycerol recovery. ${ }^{17}$

However, because these are biological macromolecules, the cost of biocatalysts and the reaction conditions commonly used in industrial processes can limit the activity and the reuse of enzymes in their free form. ${ }^{18-20}$ An alternative to circumvent this is to follow protocols of immobilization or encapsulation of such enzymes onto solid supports. These provide an increase in their stability, while facilitating their separation from the reaction medium, therefore enabling mulitple biocatalyst reuse. ${ }^{9,21-23}$

Within this context, nanostructure supports appear as strong alternatives to their conventional counterparts, since they provide additional advantageous properties such as higher surface areas. This makes them capable of retaining a higher enzymatic load per unit of particle mass and 
promotes a significant increase in mass transfer efficiency, consequently reducing diffusion limitations, and easing catalyst and product recovery. ${ }^{24-27}$ These advantages deem enzymes immobilized on nanoparticles sturdier and more attractive for a range of industrial applications.

Thus being, the present review discusses the underlying scientific context, the challenges, and the opportunities in the use of lipases for industrial processes, especially in biodiesel synthesis. It also highlights relevant enzyme properties and the strategies commonly used for immobilization. Finally, the use of nanomaterials, their properties, and their importance to existing immobilization protocols are discussed.

\section{Lipases}

Among the extensive range of existing enzymes, lipases (triacylglycerol ester hydrolases, E.C.3.1.1.3) are the most widely used ${ }^{28-31}$ due to their inherent proprieties of interest, such as high efficiency and enantioselectivity. ${ }^{32-34}$ By definition, lipases are carboxylesterases that catalyze the hydrolysis of triglycerides and other carboxylic acid esters, ${ }^{35}$ releasing glycerol and free fatty acids ${ }^{36-39}$. Under specific conditions, lipases can also perform synthesis reactions, such as esterification, transesterification (interesterification, acidolysis, and alcoholysis), aminolysis, and lactonization. ${ }^{40-42}$ Additionally, lipases have a specific and optimal $\mathrm{pH}$ activity range, ${ }^{31}$ and they do not require the presence of a cofactor. ${ }^{43,44}$ These biocatalysts serve a broad area of interest, as they act in both aqueous and organic environments. ${ }^{45}$

Structurally, most lipases have hydrophobic and hydrophilic regions, in which the enzyme near the active site undergoes enzyme-substrate interactions to promote product formation. ${ }^{32,46}$ These interactions trigger conformational (open- and closed-) changes in the enzyme, depending on which lipid interface is in operation, influencing its catalytic activity. ${ }^{47,48}$

In the presence of organic-aqueous interfaces, the catalytic activity allows most lipases to undergo a phenomenon known as interfacial activation, ${ }^{17-19}$ in which an increase in its activity occurs, observed only in the presence of insoluble surfaces. The optimal catalytic activity of lipases refers to the process of adsorption between lipase and micelle surface, in addition to the transition state of closed and open lipase conformations (Figure 1). ${ }^{49,50}$
During interfacial activations carried out in homogeneous aqueous media, lipases present a structure in which the active site is completely isolated from the reaction medium by a polypeptide chain (the 'lid'), which prevents the substrate from accessing the active site. ${ }^{50,51}$ The lid has hydrophobic residues on its inner face that interact with the hydrophobic regions around the active site when the lipase is in a closed, inactive conformation, preventing the formation of reaction products. ${ }^{29,50}$ However, when exposing lipases to hydrophobic interfaces, there is a conformational rearrangement that promotes the opening of the lid, which results in an active enzyme conformation, consequently leaving the active site free and accessible to substrates. ${ }^{52,53}$ This movement, which alternates between the active and inactive forms of the enzyme, takes place through chemical bonds between the amino acid residues of the lid with other amino acid residues present on the enzyme surface, ${ }^{50}$ as shown in Figure 1. The lipase structure from Candida antarctica (PBD code: $3 \mathrm{GUU}$ ) has been resolved both in its closed and open conformation (Figure 1).

\section{Lipase Applications}

Due to the unique properties that lipases present, they can be employed in several industrial sectors, placing them as one of the most relevant biocatalysts for biotechnological applications. ${ }^{1,29}$ They are often used in the fine chemical, ${ }^{23,54}$ food additive, ${ }^{55-59}$ agrochemical, ${ }^{60-62}$ polymer, ${ }^{63,64}$ biodiesel, ${ }^{65-69}$ detergent, ${ }^{70-72}$ and cosmetic industries, ${ }^{73-75}$ among others. ${ }^{46,76,77}$

In the food industry specifically ${ }^{25}$ lipases can be used as flavor modifiers via synthesis of short-chain fatty acids esters and alcohols, and in the obtainment of products of increased nutritional value via the modification of triacylglycerol structures by inter- or transesterification. ${ }^{78,79}$ Table 1 presents the main sources of lipases and their applications in different industrial sectors.

Lipases are used, for instance, as emulsifiers in bakery applications. ${ }^{81,91}$ They can also be used in many other processes, such as in the manufacturing dairy products, production of butter and milk equivalents, ${ }^{59}$ animal food, ${ }^{92}$ etc.

Moreover, the chemical and pharmaceutical industries are examples of sectors that use these enzymes as
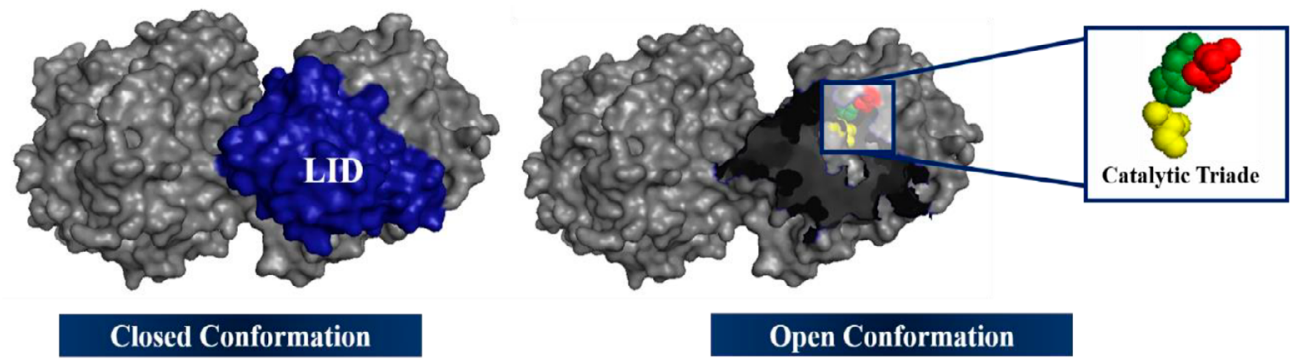

Figure 1. Closed and open conformation of lipase A from Candida antarctica (PBD code: 3GUU; 3D structure obtained with PyMol 2.2.2) 
Table 1. Applications of lipases in several industrial sectors and their deriving products.

\begin{tabular}{|c|c|c|c|c|}
\hline Lipase & Industry sector & Chemical synthesis & Final product/process & Ref \\
\hline \multicolumn{5}{|l|}{ Penicillium canesense BPF4 } \\
\hline Pseudogymnoascus roseus BPF6 & Detergent & Fat hydrolysis & Oil removal & 71 \\
\hline Hermomyces lanuginosus & Chemical & Hydrolysis & Docosahexaenoic acid & 80 \\
\hline Lactobacillus helveticuscepa & Dairy product & $\begin{array}{l}\text { Milk fat hydrolysis, cheese } \\
\text { ripening, butter modification }\end{array}$ & $\begin{array}{c}\text { Development of flavoring agents in milk, } \\
\text { cheese, and butter }\end{array}$ & 59 \\
\hline Fusarium oxysporum & Bakery & Flavor enhancer & Shelf-life extension & 81 \\
\hline Lipase B from Candida antarctica & Drink & Flavor & Beverages/soft drinks & 82 \\
\hline Malbranchea cinnamomea & Meat and fish & Flavor development & Fat removal, meat and fish products & 83 \\
\hline Aspergillus & Healthy food & Transesterification & Food products with nutritional appeal & 84 \\
\hline Rhizopus oryzae & Chemical & Transesterification & Biodiesel & 66 \\
\hline Penicillium citrinum & Fat and oil & Transesterification, hydrolysis & $\begin{array}{c}\text { Cocoa butter, margarines, fatty acids, glycerol, } \\
\text { mono- and diglycerides }\end{array}$ & 78 \\
\hline Rhizopus oryzae & Chemical & Transesterification & Biodiesel & 67 \\
\hline Aspergillus & Pharmaceutical & Transesterification, hydrolysis & Specific, digestive lipids & 85 \\
\hline Candida rugosa & Chemical & Esterification & Biolubricants & 68 \\
\hline Candida antarctica lipase B & Cosmetic & Synthesis & Emulsifiers, Humidifiers & 75 \\
\hline Rhizoтисот miehei & Chemical & Esterification & Biodiesel & 3 \\
\hline Yarrowia lipolytica & Paper & Hydrolysis & Paper quality improvement & 86 \\
\hline Rhizomисо miehei & Chemical & Esterification & Catalytic property improvement & 87 \\
\hline Aspergillus & Cleaning & Hydrolysis & Fat removal & 84 \\
\hline Yarrowia lipolytica & Leather & Hydrolysis & Leather products & 86 \\
\hline Candida antarctica & Chemical & Esterification & Biodiesel & 14 \\
\hline Lipase B from Candida antarctica & Cosmetic & Aminolysis reactions & Amphiphilic amide production & 75 \\
\hline Pseudomonas fluorescens & Chemical & Transesterification & Biodiesel & 88 \\
\hline Rizomисо miehei & Chemical & Hydrolysis & Selective hydrolysis of fish oil & 89 \\
\hline Pseudomonas fluorescens & Chemical & Enantioselectivity, synthesis & Construction of chiral blocks & 90 \\
\hline
\end{tabular}

biocatalysts. Enzyme-aided processes in these areas have grown considerably in recent years. Lipases can be used in surfactant production ${ }^{93}$ solving racemic mixtures, ${ }^{7}$ detergent formulation ${ }^{94}$ treatment of residues rich in oils and fats, as well as in healthcare, medicine production, diagnostics, cosmetics and antibiotics. ${ }^{19}$

In the biofuel industry, biodiesel production is constantly cited as one of the possible applications of lipases. ${ }^{14,16,18,95,96}$ Biodiesel has gained strong relevance in recent times due to the possibility of fossil fuel substitution. The environmental issues identified and related to the emission of gases from fossil fuels have driven research into developing alternative fuels, including biodiesel. ${ }^{97}$ The use of new biofuel production techniques (for bioethanol and biodiesel) is a viable alternative to replace fossil oils, since these are considered green technologies. ${ }^{15}$

\section{Lipase Immobilization}

Enzymes for enzymatic processes can be employed in free or immobilized forms. ${ }^{23}$ However, using free enzymes usually results in molecule instability, rapid loss of catalytic activity, and the impossibility of separating and regenerating catalysts for future reuse. These factors directly and strongly influence process control, which consequently affect the the associated manufacturing cost, especially in processes run under industrial scales. ${ }^{19,98}$

Based on the different lipase properties, the range of applications enabled by their immobilization, as well as the intense current research on the topic, researchers around the world have been looking for new ways of using, improving, and developing existing immobilisation protocols. It is clear that the application of lipases in biotechnological process is considered a flourishing and promising research field. ${ }^{29}$

Enzymatic immobilization is achieved when enzyme molecules are confined to a solid matrix ('support') different from that in which the substrate or products are present, ${ }^{99}$ i.e., by binding the enzymes or inserting them into a suitable support material..$^{29}$ The primary purpose of enzyme immobilization is to create biocatalysts that are resistant enough to work under different, and sometimes severe, operational conditions, while presenting improved stability, catalytic activity, and the possibility of reuse of biomolecules over successive catalytic cycles, prolonging their lifetime. ${ }^{100,101}$ Many types of supports and materials have been described as efficient for lipase immobilization in the literature, among which are silica, glass beads, ceramics, chitosan, graphene, magnetic supports, and polymeric microspheres. ${ }^{102}$ 
Ideally, the immobilized enzyme should exhibit a superior catalytic activity compared to its free form. ${ }^{102}$ Besides, there should be no changes to either the active site of the enzyme or its structural conformation. ${ }^{103}$ However, enzymatic immobilization may in fact increase or inhibit enzyme activity and stability. ${ }^{104} \mathrm{To}$ resolve the instability problems and optimize them for various applications, different physical and chemical immobilization methods are used. Some of those immobilization techniques (Figure 2), such as adsorption, encapsulation, entrapment, covalent bonding, and crosslinking ${ }^{22,23,100}$ have been reported in the literature and are discussed below.

\subsection{Adsorption}

Physical adsorption is a direct and reversible immobilization method involving enzymes adsorbed onto the support material through a physical or chemical way. It is considered the simplest method of immobilization, ${ }^{105}$ which justifies being the one most employed industrially, usually involving lipases immobilization onto hydrophobic supports. ${ }^{45}$

The forces established between the enzyme and the support during immobilization are weaker, such as Van der Waals electrostatic forces, ionic, and hydrogen bonding interactions. ${ }^{22}$ Although these interactions are fragile, they are stable enough to allow proper bonding and stabilization, ${ }^{106}$ especially when reactions are carried out in organic media since, under these conditions, the enzyme is insoluble in nonpolar environments.

In short, the adsorption process takes place by mixing an aqueous enzyme solution with the support material for a set amount of time. ${ }^{107}$ The reaction runs at preset and constant conditions of temperature, $\mathrm{pH}$, and ionic strength. ${ }^{105}$ Sequentially, the enzyme excess is washed from the support. ${ }^{108}$ The strict control of these reaction conditions is essential, as these can alter the ideal parameters and compromise adsorption rates and yields.

The technique is advantageous due to the easy and straightforward immobilization protocol followed, which results in reduced costs. Moreover, unlike other techniques, the support does not need previous activation, since there are no significant changes to the enzyme conformational structure. ${ }^{22}$ On the other hand, an easy desorption can be caused by inconsistent control of temperatures, $\mathrm{pHs}$, and ionic forces, which can lead to enzymatic losses. ${ }^{109}$ However, this facilitated desorption can also be seen as advantageous, as it allows for an easier recovery of the support after enzyme denaturation, thus enabling its reuse in various subsequent cycles. ${ }^{110}$

Nevertheless, some key factors must be taken into account so that immobilization by adsorption is carried out successfully. These include protein sizes, adsorbent surface area, pore size, ${ }^{111}$ and enzyme concentration. It is worth highlighting that the amount of enzyme adsorbed per amount of support increases with the concentration of the biocatalyst, which may lead to rapid or premature saturation. ${ }^{106,112}$

\subsection{Encapsulation and entrapment}

Encapsulation and entrapment in a small space are also very common methods in enzyme immobilization protocols. ${ }^{20,106,113}$ These are based on the in situ polymerization of the porous matrix around the biocatalysts to be immobilized. ${ }^{114}$ Thus, the enzyme is incorporated as part of the reaction polymerization mixture. For both encapsulation and entrapment methods, gel pore size is a significant factor to be considered. ${ }^{115}$

Encapsulation refers to the envelopment of the enzyme in a semipermeable membrane or microcapsule. When

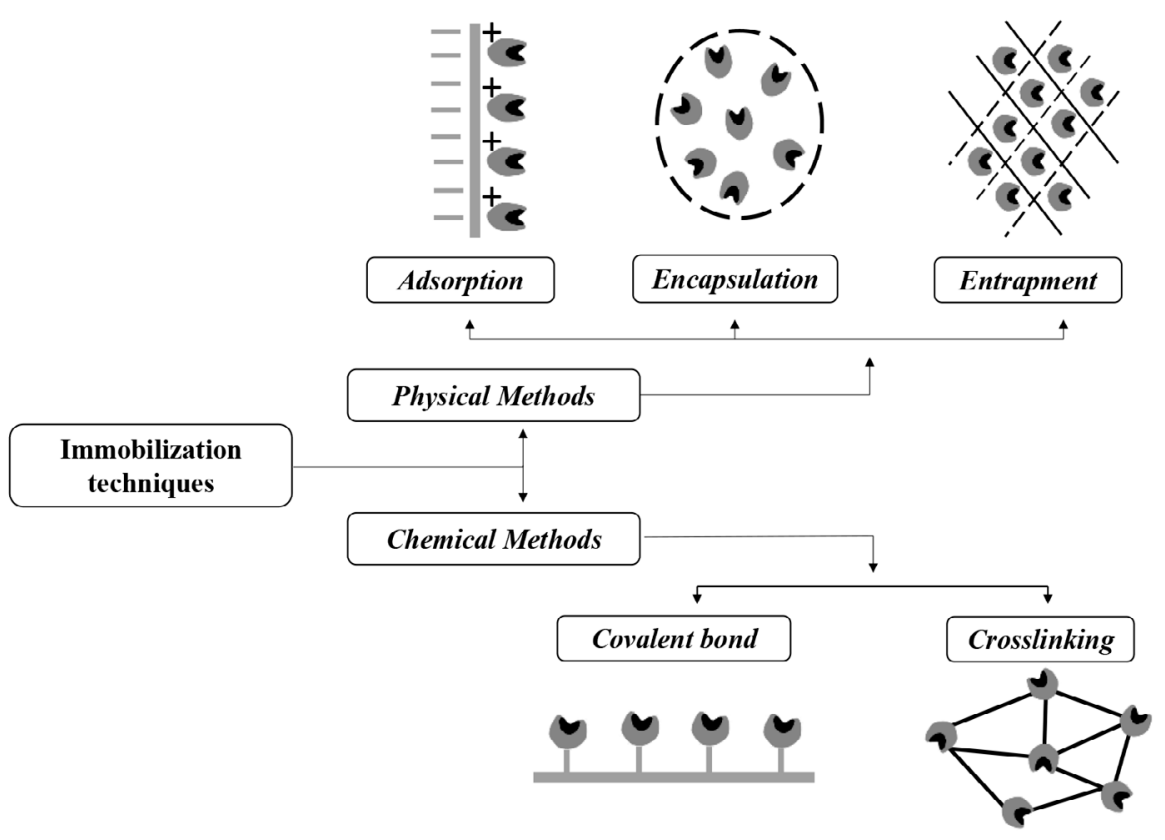

Figure 2. Main techniques used in enzyme immobilization 
confinement specifically occurs in a polymeric capsule or matrix, this is called entrapment. ${ }^{1}$ These membranes or matrices should have small enough pores to allow the passage of enzymes (macromolecules), but offer free passage to products and substrates. ${ }^{116}$ The enzymes that remain in solution protect them from external effects. ${ }^{106}$ Despite the advantage of not causing enzyme structural changes, this method may not be applicable in some cases, such as when the enzyme-substrate complex is too large to pass through the pores of the encapsulating materials. ${ }^{106,117}$

The use of polysaccharide alginate as a support is one of the most common routes for encapsulation. ${ }^{118}$ Enzyme immobilization onto alginate occurs easily by dripping a solution of alginate containing the enzyme into a solution rich in calcium ions. ${ }^{119}$ The formed polymer network then traps the enzyme in micropores, giving the encapsulated enzyme better protection, as it blocks its direct contact with the reaction medium; as a consequence, inhibition effects are reduced. ${ }^{22,120}$

Enzymatic immobilization by entrapment is done based on the specific enzyme occlusion within a restrictive porous structure. Thus being, the process allows the diffusion of substrates and products, while blocking the protein penetration through the pore structure. ${ }^{105} \mathrm{After}$ entrapment, lipases are then attached to the polymeric matrix or capsule, causing restricted diffusion. The types of membranes used to this end include cellulose acetate, polycarbonate, collagen, and Teflon. ${ }^{121}$

The maintained stability is pointed out as an advantage of these protocols ${ }^{12}$ since physical interactions or chemical bonds are not established between the enzyme and the support. Also, a high surface area of contact between the substrate and the enzyme can be provided by a relatively small volume, allowing for higher catalytic activities. ${ }^{110}$ Another advantage is the possibility of immobilizing multiple enzymes to the matrix in the same process.

As for disadvantages, only low molar mass substrates can be used in this type of processes due to the fact that proteins with high molar masses cannot penetrate the capsules. ${ }^{122}$ Other disadvantages to be mentioned are the possibility of enzyme inactivation during the immobilization protocol, which results in a need for high enzyme concentrations to guarantee encapsulation, and in possible inhibitory effects by products or substrates within the porous matrix. ${ }^{23}$ Additionally, apart from the limited mass transfer rates from the matrix pores to the immobilized enzyme, the support can become corrupted due to polymerization and release the enzyme, resulting in its inactivity. This also indicates that the method presents a low capacity of enzyme charge retention. ${ }^{122,124}$

\subsection{Covalent attachment}

Covalent bonding occurs by reactive support groups, activated or not, with the functional groups of the group- linking enzyme - $\mathrm{NH}_{2},-\mathrm{COOH},-\mathrm{OH},-\mathrm{SH}$, among others. ${ }^{25}$ This is preferably carried out under mild physiological conditions, low temperatures and ionic strengths, optimum $\mathrm{pHs}$, and often in the presence of substrates, in order to protect the active site of the enzyme and prevent activity loss. ${ }^{106}$

The covalent immobilization protocol is employed when the final product needs to be entirely free of enzyme residues. ${ }^{22}$ Therefore, to successfully achieve the product of interest, a high stability between the biocatalyst and the matrix must be guaranteed. Also, it is essential to highlight that this procedure requires the chemical modification of the support surface in order to obtain reactive intermediate groups; this modification is made through activation reactions. Glutaraldehyde (GLU) is commonly used in this context as a reagent in support-activation reactions, or as a spacer arm, due to its low cost and high reactivity. ${ }^{45}$ The bonds formed between the enzyme and glutaraldehyde are stable owing to its the good control of key parameters, such as $\mathrm{pH}$, ionic strength, solvents, and temperature. ${ }^{22}$

This method presents high thermal and operational stability in comparison to other techniques. The biocatalyst also presents higher resistance to variations in $\mathrm{pH}$, temperature, and to incubation in organic solvents, so the enzyme does not desorb from the support. In contrast, compared to other methods and considering the total cost of the process, there is a relatively lower immobilization yield, since the enzyme-support binding process is irreversible. ${ }^{122}$ Another disadvantage is that this protocol can lead to partial or total loss of catalytic activity due to changes in protein morphology induced by multiple attachment points between the enzyme and the support. ${ }^{22,106}$

\subsection{Crosslinking}

A particular type of covalent bond immobilization is crosslinking. ${ }^{9}$ In this method, the enzymes are tightly linked together by the use of a multifunctional compound such as glutaraldehyde. ${ }^{126}$ The binding efficiency of this method deems enzymatic loss in the support negligible. It is also considered to be a simple technique. In contrast, some disadvantages associated with crosslinking are the production of fragile particles, limited diffusion, ${ }^{22}$ high operational costs, and the impossibility of support regeneration. ${ }^{127}$ In addition to these, a conformational modification of the enzyme may occur due to multiple bonds, which leads to partial or total loss of catalytic activity. ${ }^{101}$

Despite the variety of physical and chemical techniques applied to enzyme immobilization, there is no specific method that can be considered applicable to all enzymes. Although each immobilization method has advantages and disadvantages, the choice of protocol and the modification of the support must take into account the key factors described above, involving: the interactions regarding the support, the enzyme, and the substrate; its physical parameters $(\mathrm{pH}$, 
temperature, ionic strength, enzyme concentration); the ease of operation and economy of the protocol; activity retention and overall operational stability, etc.

\section{Nanomaterial Properties for Lipase Immobilization}

In this section, the use of nanomaterials for the immobilization of lipases aiming at biofuel production is reviewed. Biofuel production can take place in catalyzed (homogeneous and heterogeneous) or non-catalyzed systems. ${ }^{128}$ To date, soluble or immobilized lipases, as biological catalysts, are the most promising enzymes for biofuel production. ${ }^{32}$ The production of fuels from biomass feedstocks catalyzed by lipases is a reasonably novel strategy and it is still the subject of ongoing scientific research. ${ }^{129}$

Nevertheless, to use lipases in the production of biofuels, there is a clear need to optimize their native properties. ${ }^{130}$ In this regard, it is possible to improve enzyme activity, specificity, selectivity, stability, and reduce their inhibition through advances in enzyme engineering techniques, such as enzyme immobilization. ${ }^{104}$ In this technique, the material of the immobilization support for may significantly impact the activity, stability, and orientation of the enzyme. ${ }^{21}$ Within this context, nanomaterials (nanometric systems $\left(10^{-9} \mathrm{~m}\right)$ ), can be said to be very efficient support materials for lipase immobilization, ${ }^{131,132}$ since they can mitigate mass transfer resistance phenomena and, therefore, ameliorate diffusional problems; besides, nanomaterials present a high surface area, thereby enabling effective enzyme loading, and, in the case of magnetic nanomaterials, resulting in facilitated recovery and reuse of the magnetic nano-biocatalyst. ${ }^{98}$

Nanoparticles (NPs), nanotubes (NTs), and nanofibrous membranes (NFMs) are the most commonly-used nanomaterials for lipase immobilization. ${ }^{26}$ Remarkably, magnetic nanoparticles (MNPs) are used as supports for the immobilization of enzymes. ${ }^{133}$ Lipases have already been successfully immobilized onto MNPs aiming at the production of biofuels. For instance, lipase B from Candida antarctica (CALB) was immobilized onto (3-glycidoxypropyl) trimethoxylsilane-functionalized MNPs to catalyze the transesterification of waste cooking oil with methanol to fatty acid methyl esters (FAMEs). Yields of almost $100 \%$ conversion in the presence of molecular sieves were observed; also, the process derivate showed excellent reusability, retaining $100 \%$ of its initial activity even after six reaction cycles. ${ }^{134}$ Similarly, lipase from Aspergillus terreus (AH-F2) was immobilized onto polydopaminefunctionalized MNPs to catalyze the transesterification of waste cooking oil with methanol for FAMEs synthesis, reaching $92 \%$ conversion at $10 \%$ derivate percentage concentration, 6:1 $\mathrm{CH}_{3} \mathrm{OH}$ to oil ratio, temperature of $37^{\circ} \mathrm{C}$, $0.6 \%$ water content, and $30 \mathrm{~h}$ of reaction time. ${ }^{135}$

Additionally, metal-organic frameworks (MOFs) are a novel nanomaterial for lipase immobilization with interesting properties. ${ }^{39}$ Being crystalline porous nanomaterials, MOFs are based on the interconnection of metal ions or metal clusters, and organic ligands. ${ }^{136} \mathrm{MOFs}$ can therefore improve catalytic efficiency, enhance chemical and thermal stability, promote accessibility to active sites, and allow and facilitate recyclability and increase enzyme loading.$^{137}$ Similarly, hybrid organic-inorganic nanoflowers have been explored as a new immobilization strategy. In this technique, enzymes and metal ions act as organic and inorganic components, respectively, to form hybrid nanoflowers (HNFs). This immobilization method is easy to perform, grants excellent catalytic efficiency to the enzyme, and increases its stability; also, the hybrid nanoflower biocatalytic system demonstrates high catalytic activity and stability in a wide range of experimental conditions compared to free and conventionally-immobilized enzymes. ${ }^{8,133}$

Lipase immobilization onto nanomaterials can enhance their catalytic performance through rationing and optimization. ${ }^{138}$ High mechanical strength and surface area, active enzyme loading, good mass transfer rates, and the minimization of diffusional problems are commonly claimed as advantageous properties of nano-supports aimed at lipase immobilization, ${ }^{139,140}$ Besides, there is the possibility of synthesizing nanomaterials with well-defined particles with adjustable size and the immobilizing these onto nanomaterials for reducing protein unfolding. ${ }^{26,131}$ Although the enhancement of enzymatic performance depends on the type of lipase, support material, and the immobilization conditions and strategies, the immobilization of lipases onto nanomaterials is usually reported to increase their activity, stability (temperature, $\mathrm{pH}$, solvent, and storage), apart from facilitating their recovery and subsequent reuse. ${ }^{138}$

Immobilization onto nanomaterials have been shown to alter the activity, stability and even modulate native lipase functions. ${ }^{141}$ For example, Monteiro et al. ${ }^{142}$ showed that immobilization by covalent bonding of lipase A from Candida antarctica in MNPs functionalized with chitosan and activated with glutaraldehyde successfully increased the activity and thermal stability of the biocatalyst up to 11 fold. There was also an increase in the operational stability of the derivative used by up to 7 consecutive cycles, which retained $50 \%$ of its initial activity even in a very viscous medium, such as in the case of the production of a biolubricating ester. ${ }^{142}$ Similarly, Verna et al. ${ }^{143}$ demonstrated that it is possible to increase the thermal and operational stability of a lipase from Thermomyces lanuginosus immobilized onto multi-walled carbon nanotubes that had been aminofunctionalized and activated with glutaraldehyde. ${ }^{143}$

Via interfacial activation in the presence of a hydrophobic support, lipases can be more strongly adsorbed, shifting the equilibrium towards their open conformation and causing an increase in enzyme activity through this type of activation..$^{144,145}$ In this regard, the hydrophobic interactions at the nanoscale are more robust than at the microscale; therefore, it may affect the structure of the lipase, enhancing the opening of the lid, which consequently improves catalytic activity and stability. ${ }^{26}$ 
Nevertheless, nanomaterials may present some drawbacks in lipase immobilization, such as large-scale application limitations, high fabrication cost, enzyme entrapment in the pores of nanoporous materials, and enzyme separation from the reaction medium, except when using magnetic nanomaterials (Figure 3) ${ }^{138}$ Furthermore, the very high surface area tends to maximize the contact of the lipase with the surface of the nanomaterials, which may cause changes in its conformation and affect its activity. ${ }^{146}$

Moreover, as they are very small particles with a high surface area, nanomaterials are inherently prone to aggregation, making paramagnetism and nanobiocatalyst dispersibility difficult. ${ }^{147}$ The aggregation problem could be avoided using specific reagents. Particularly, functionalization or activation of these nanomaterials with polyethyleneimine, (3-Aminopropyl)triethoxysilane, glutaraldehyde, or divinyl sulfone, for example, could prevent the phenomenon from taking place. ${ }^{148}$

Recently, multienzyme co-immobilization onto nanomaterials has gained prominence due to its multiple application capabilites. ${ }^{149} \mathrm{On}$ this subject, the most used oils for biodiesel production are heterogeneous substrates ${ }^{150}$ therefore, the use of different lipases with complementary selectivity for the substrates' free fatty acids may enhance the efficiency of the biodiesel production process. ${ }^{151}$ So far, to the best of the authors' knowledge, there are no reports in the literature on the use of nanomaterials for co-immobilizing lipases for the production of biofuels. However, it is possible to find records on the use of a combination of commercial preparations of lipases ${ }^{151}$ or even on the co-immobilization of a combination of lipases in non-nanostructured supports ${ }^{152}$ to this end; in both systems, efficiency was increased with the use of combined lipases.

\section{Biodiesel Production via Lipase Immobilized on Nanomaterials}

As discussed above, immobilized lipases are highly relevant catalysts in biofuel production. ${ }^{45,110,153,154}$ Apart from all the aforementioned advantages, they also foster process sustainability by reducing or even removing the need for additional feedstock-pretreatment and product-purification steps. ${ }^{4,8}$ However, the inherent high costs and specific process limitations prevent industrial-scale applications. ${ }^{155}$ In this context, many studies were conducted, and among these, the application of nanomaterials as carriers for lipases has gained significant interest and brings great potential for the scale up of biofuel production processes. ${ }^{156,157}$

As mentioned in the last section, amid possible lipase supports, nanomaterials are being reported to increase efficiency of biofuel production in several studies due to their desired characteristics of versatility (they can be produced from different natural sources) and large surfaceto-volume ratio, which provides ample surface area for lipase immobilization and increases their stability, simultaneously providing better stability and reusability ${ }^{157-160} \mathrm{Also}$, the rate of diffusion in the active site of the enzymes is enhanced due to the minuscule pore sizes found in nanomaterials, determined by the square of the diffusion path that accesses the site $(\mathrm{Eq} 1$, in which is the diffusion rate of reactant to the active sites of the enzyme, and is the diameter of the diffusion path of reactants accessing the active sites of enzymes).

$$
R_{d f} \propto \frac{1}{D^{2}}
$$

Thus, by reducing the diffusion path diameter, one can increase the diffusion rates and consequently, accelerate the reaction process. ${ }^{157}$ In biofuel production, lipases are mainly used to catalyze transesterification reactions to produce biodiesel, a fuel with high potential of reducing combustion emissions. ${ }^{161,162}$ Biodiesel is mostly widely produced from renewable biomass resources, such as edible vegetable oils, but low-cost feedstock have also been studied as alternatives, aiming at reducing competition with food production materials and prices. ${ }^{157,160}$ Inedible and used cooking oils, as well as animal fats and greases are examples of the other raw materials, but their supply is insufficient to meet the global demand for fuel. ${ }^{163}$ In addition to these, microalgae is also a resource with growing interest, since they reduce land requirement for production due to being grown in wastewater, apart from having high growth rates

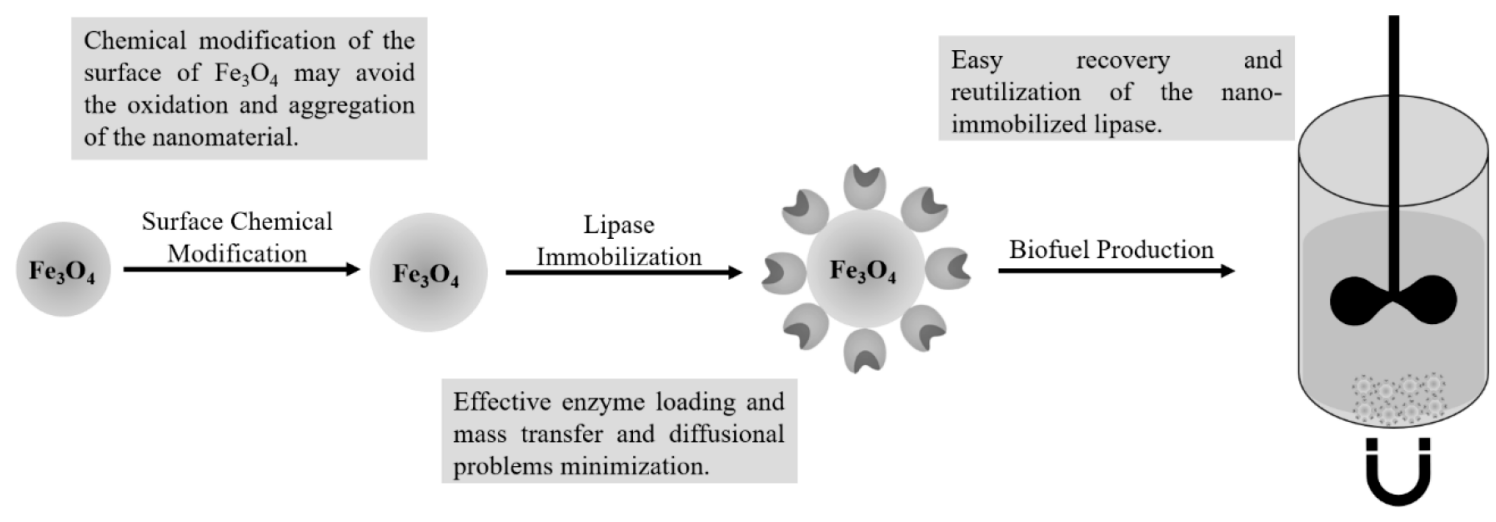

Figure 3. Immobilized lipase onto functionalized-MNPs 
and lipid content. ${ }^{157,161,164}$ In this context, many studies have investigated the effects of using nanomaterials as carriers for different lipases. These are listed in Table 2.

Carbon nanotubes are the leading alternatives among the carbonaceous supports for lipase immobilization. ${ }^{184}$ In this category, multi-walled nanotubes showing high efficiency, mechanical strength, and low throughput requirement are usually employed. ${ }^{185}$ Further induction of magnetic properties in these carriers enhances their potential, facilitating the separation of reactants at the end of the process, and reducing energy consumption. ${ }^{185}$ Catalyst separation can be a problem in some process since they may require more than one simple centrifugation and, as with similar situations, incur on additional energy costs. ${ }^{157}$ Therefore, many studies are focused on magnetic nanoparticles, as shown in Table 2. Fan et al. (2017) prepared multi-walled carbon nanotubes by filling them with iron oxide and further linking them with polyamidoamine dendrimers on their surface. ${ }^{180}$ The carrier was employed to immobilize a Burkholderia cepacia lipase via a covalent method, which provided a specific activity 17 -fold higher than that of the free enzyme, apart from enhanced thermostability and $\mathrm{pH}$ resistance. The biocatalyst prepared was used to produce biodiesel at a conversion rate of $92.8 \%$, with an excellent recycling performance and a catalytic activity over $90 \%$ of its original activity after 20 cycles, showing easy separation through the use of a magnet. ${ }^{180}$
The scaleup of a biodiesel production process to an industrial level not only requires successful immobilization and efficient laboratory synthesis, but also the design and operation of appropriate high-volume reactors. ${ }^{168}$ In this context, many reactors configurations have been evaluated, and some of them, projected for lipase immobilized in nanostructured materials, as discussed below.

Previous studies proved that batch operations are not suited for this purpose since they are considered time-consuming, labor-intensive, and not well suited for automation. ${ }^{186} \mathrm{On}$ the other hand, continuous processes have shown some advantages over batch, since production costs and times are adjusted according to the necessary work level, the amount of biodiesel obtained per labor unit, and the simplicity of optimizing biodiesel quality. ${ }^{168} \mathrm{In}$ their continuous production system, Wang (et al., 2011), using a Pseudomonas cepacia lipase immobilized in $\mathrm{Fe}_{3} \mathrm{O}_{4}$ nanoparticles, obtained better results of conversion and stability using a four-packedbed reactor than those achieved using a single-packed-bed reactor. ${ }^{168}$ By using the four-packed-bed configuration, the process retained its original biodiesel conversion levels. Therefore, the reactor has been proved to be an excellent option for achieving the design and operation of an enzymatic biodiesel production at an industrial level. ${ }^{168}$

Another alternative is to use microchannel reactors, which parallelize in order to scale up production and are easy to operate under continuous mode and constrained environments. ${ }^{187}$ The main advantages in these reactors

Table 2. Nano-immobilized lipases reported in biodiesel production

\begin{tabular}{|c|c|c|c|c|}
\hline Feedstock & Lipase source & Nanocatalyst & Yield ( \%) & Ref \\
\hline Soybean oil & Thermomyces lanuginosa & $\mathrm{Fe}_{3} \mathrm{O}_{4}$ & 90 & 165 \\
\hline Rapeseed oil & Pseudomonas cepacia & Poly-acrylonitrile fibers & 80 & 166 \\
\hline Soybean oil & Pseudomonas cepacia & Poly-acrylonitrile nanofibrous membrane & 90 & 167 \\
\hline Soybean oil & Pseudomonas cepacia & $\mathrm{Fe}_{3} \mathrm{O}_{4}$ & 88 & 168 \\
\hline Olive oil & Burkholderia sp. & $\mathrm{Fe}_{3} \mathrm{O}_{4}-\mathrm{SiO}_{2}$ & $>90$ & 169 \\
\hline Grease & Candida Antarctica and Thermomyces lanuginosus aggregates & $\mathrm{Fe}_{3} \mathrm{O}_{4}$ & $>97$ & 170 \\
\hline Olive oil & Burkholderia sp. C2O & Alkyl grafted core-shell $\mathrm{Fe}_{3} \mathrm{O}_{4}-\mathrm{SiO}_{2}$ & 95.74 & 171 \\
\hline Jatropha oil & Pseudomonas Fluorescens) & Carbon nanotubes & 90 & 172 \\
\hline Palm oil & Thermomyces lanuginosus & $\mathrm{Fe}_{3} \mathrm{O}_{4}$ & 97.2 & 173 \\
\hline Soybean oil & Pseudomonas cepacia & $\mathrm{Fe}_{3} \mathrm{O}_{4}$ coated with polydopamine & 90 & 174 \\
\hline Canola oil & $\begin{array}{c}\text { Candida Antarctica Thermomyces lanuginosus } \\
\text { Rhizomucor miehei }\end{array}$ & Epoxy-functionalized silica & 98 & 175 \\
\hline Soybean oil & Thermomyces lanuginosus & $\mathrm{Fe}_{3} \mathrm{O}_{4}$ & 100 & 176 \\
\hline Canola oil & Burkholderia cepacia & $\mathrm{Fe}_{3} \mathrm{O}_{4} @ \mathrm{SiO}_{2}$ & 91 & 177 \\
\hline Sunflower oil & Burkholderia & Alkyl-celite & 85 & 178 \\
\hline Waste vegetable oil & Candida sp. & $\mathrm{Fe}_{3} \mathrm{O}_{4}$ sub-microspheres & 80 & 179 \\
\hline Soybean oil & Burkholderia cepacia & Superparamagnetic Multi-walled carbon nanotubes & 93 & 180 \\
\hline Waste vegetable oil & Candida antarctica & $\mathrm{Fe}_{3} \mathrm{O}_{4} @ \mathrm{SiO}_{2}$ & 100 & 135 \\
\hline Rapeseed oil & Candida antarctica & $\mathrm{Fe}_{3} \mathrm{O}_{4}$ & 89 & 181 \\
\hline Brown grease & Candida rugosa & $\mathrm{Fe}_{3} \mathrm{O}_{4}$ & 100 & 182 \\
\hline Soybean oil & Aspergillus niger & $\mathrm{Fe}_{3} \mathrm{O}_{4} @ \mathrm{SiO}_{2}$ & $>90$ & 183 \\
\hline
\end{tabular}


are their large surface to volume ratio and shorter reaction times. ${ }^{188}$ The specific surface area of microchannel reactors allows for a more active molecular diffusion, which eliminates adverse side reactions, creates hot spots within channels, and induces rapid mixing rates. ${ }^{187}$

Also, active micromixers using magnetic forces have gained more attention recently due to their simple design, fabrication process, and easy integration to microfluidic chips. In a specific study, Mohammadi et al., (2017), excited magnetic nanoparticles under a magnetic field to increase biodiesel production efficiency. ${ }^{184}$ Four different micromixers, with ring-shaped and pitted-mixing channels, with and without a T-junction, were tested under static and rotating magnetic fields. By using the pitted type channels with a T-junction under a rotating magnetic field, the authors were able to obtain a maximum biodiesel yield of $98.1 \%{ }^{184}$

\section{Future Trends and Conclusions}

Due to the growing demand for energy and the increased environmental pollution, the depletion of fossil fuel reserves and fluctuations in energy prices have led to an urgent need for sustainable and clean energy resources. To this end, some initiatives aiming at the production and implementation of biofuels have been developed in many countries. ${ }^{160,189,190}$

However, biofuel production processes still present hurdles (such as by-product generation in biodiesel production) that need to be overcome before more environmentally friendly processes can be achieved. Therefore, the use of lipases, especially in their immobilized forms, may be a viable alternative for overcoming such problems since, besides presenting higher selectivity, are also versatile in terms of their applicability, which enables the generation of secondary products in small or even null concentrations. They can also be reused in consecutive reaction cycles, depending on the process and the immobilization technique used. ${ }^{15,160,191-193}$

Conventional immobilization methodologies using different supports ${ }^{194-199}$ and immobilization routes can cause the reduction of specific enzymatic activity during their use. ${ }^{105,200}$ Thus being, employing nanomaterials for lipase immobilization is a promising strategy due to their several inherent advantages, such as the use of metallic nanoparticles as a support in the immobilization phase for improving enzymatic activity and stability, by increasing surface area and enhancing enzymatic immobilization. ${ }^{201,202}$ The main advantage of using immobilized lipases supported by nanomaterials is their ease of recovery and reuse, resulting in reduced process costs. However, enzymes have distinct immobilizing characteristics that can complicate the elucidation of the conformational changes taking place as they interact with the nanomaterials. ${ }^{24,203,204}$

Another application of nanomaterials is as a support in enzyme co-immobilization protocols. Studies report that the immobilization of two or more lipases induces better interactions, causing microenvironmental effects and cascading kinetic reactions, all of which result in an elevation of the general enzymatic activity compared to the immobilization of one single lipase. ${ }^{149,200}$ This strategy could be employed to facilitate various processes involving the hydrolysis of complex substrates and in biofuel production. ${ }^{190}$ By immobilizing several enzymes in nano-supports, biocatalysts can count on various catalytic activities, and recovery and reuse is made easier. These nano-supports can also be promptly used in batch and flow reactors due to the unique properties of the nanomaterials, such as magnetism and porous conformation. ${ }^{149,205}$

Nanomaterials can play an essential role in the development and consolidation of sustainable energy production processes because of their intrinsic properties. However, accelerating the application of nanoparticles in bioprocesses requires current and future research to solve, or at least ameliorate, the various aforementioned technical hurdles by, for instance, investigating the synthesis of non-toxic microorganisms, the use of lower-cost and environmentally-friendly nanomaterials, and the analysis of the behavior and the performance of nanoparticles of different shapes and sizes, in different bioprocesses. ${ }^{160,190}$

It is essential to mention that the use of enzymes on the catalysis of biofuel synthesis currently faces implementation difficulties caused by the high costs and low stability of these catalysts. ${ }^{206}$ However, using nanotechnology, some of these problems could be reduced via enhancement of their catalytic activity, mechanical strength, stability to the reaction medium, and easy reusability with magnetic carriers. ${ }^{207,208}$ Such advantages have been confirmed when allied with the high efficiencies and the reduced reaction times observed. However, since the technology is still in its early stages, further investigation is necessary, including techno-economic assessments of nano-immobilized lipases as biocatalysts for large-scale biodiesel production processes. ${ }^{160}$ Thus, the application of biocatalysts under industrial scales must be optimized observing the type of enzyme to be used, the process in which they will be carried out, the final product of interest, the reaction media employed, among other factors. ${ }^{209,210}$ It also needs to be considered that enzymes can become inactive if these parameters are not consistent with their physical-chemical requirements. ${ }^{185}$ Therefore, by taking into account all the topics discussed in this review, it is essential to combine the bio- with the nano-technology to create robust and efficient nano-bio-catalytic systems, which has high potential for granting more economic feasibility in biofuel production.

\section{Acknowledgments}

We gratefully acknowledge the financial support of the following Brazilian agencies for the Scientific and 
Technological Development: Fundação Cearense de Apoio ao Desenvolvimento Científico e Tecnológico (FUNCAP BP3-0139-00005.01.00/18), Conselho Nacional de Desenvolvimento Científico e Tecnológico (CNPq, 408790/2016-4, 422942/2016-2 and 311062/2019-9), and Coordenação de Aperfeiçoamento de Ensino Superior (CAPES-Finance Code 001).

\section{References}

1. Reis, C.; Sousa, E.; Serpa, J.; Oliveira, R.; Oliveira, R.; Santos, J.; Design of immobilized enzyme biocatalysts: drawbacks and opportunities. Química Nova 2019, 43, 1. [CrossRef]

2. Sarmah, N.; Revathi, D.; Sheelu, G.; Yamuna Rani, K.; Sridhar, S.; Mehtab, V.; Sumana, C.; Recent advances on sources and industrial applications of lipases. Biotechnology Progress 2018, 34, 5. [CrossRef]

3. Aguieiras, E. C. G.; de Barros, D. S. N.; Sousa, H.; FernandezLafuente, R.; Freire, D. M. G.; Influence of the raw material on the final properties of biodiesel produced using lipase from Rhizomисor miehei grown on babassu cake as biocatalyst of esterification reactions. Renewable Energy 2017, 113, 112. [CrossRef]

4. Pedro, K. C. N. R.; Parreira, J. M.; Correia, I. N.; Henriques, C. A.; Langone, M. A. P.; Enzymatic biodiesel synthesis from acid oil using a lipase mixture. Química Nova 2018, 41, 284. [CrossRef]

5. Goswami, A.; Goswami, J.; DMSO-triggered enhancement of enantioselectivity in Novozyme[435]-catalyzed transesterification of chiral 1-phenylethanols. Tetrahedron Letters 2005, 46, 4411. [CrossRef]

6. Hasan, F.; Shah, A. A.; Hameed, A.; Industrial applications of microbial lipases. Enzyme and Microbial Technology 2006, 39, 235. [CrossRef]

7. Virgen-Ortíz, J. J.; dos Santos, J. C. S.; Ortiz, C.; BerenguerMurcia, Á.; Barbosa, O.; Rodrigues, R. C.; Fernandez-Lafuente, R.; Lecitase ultra: A phospholipase with great potential in biocatalysis. Molecular Catalysis 2019, 473, 110405. [CrossRef]

8. Aarthy, M.; Saravanan, P.; Gowthaman, M. K.; Rose, C.; Kamini, N. R.; Enzymatic transesterification for production of biodiesel using yeast lipases: An overview. Chemical Engineering Research and Design 2014, 92, 1591. [CrossRef]

9. Monteiro, R. R. C.; dos Santos, J. C. S.; Alcántara, A. R.; Fernandez-Lafuente, R.; Enzyme-Coated Micro-Crystals: An Almost Forgotten but Very Simple and Elegant Immobilization Strategy. Catalysts 2020, 10, 891. [CrossRef]

10. Escamilla-Alvarado, C.; Pérez-Pimienta, J. A.; Ponce-Noyola, T.; Poggi-Varaldo, H. M.; An overview of the enzyme potential in bioenergy-producing biorefineries. Journal of Chemical Technology \& Biotechnology 2017, 92, 906. [CrossRef]

11. Okonko, I. O.; Egwame, R. A.; Fajobi, E. A.; Nkang, A. O.; Iheakanwa, C. I.; Ogunnusi, T. A.; Onajobi, B. I.; Current trends in biofuel production and its use as an alternative energy security. Electronic Journal of Environmental, Agricultural and Food Chemistry 2009, 8, 1233. [CrossRef]
12. Luna, C.; Luna, D.; Calero, J.; Bautista, F. M.; Romero, A. A.; Posadillo, A.; Em Handbook of Biofuels Production, 2nd ed, Lin, C.S.K., Wilson K., Clark J., (eds), Elsevier: Amsterdam, 2016, 167. [CrossRef]

13. Al-Zuhair, S.; Em Energy, Handbook of Biofuels Production, Luque, L.; Campelo, J.; Clark, J., (eds), Elsevier: Amsterdam, 2011, 134. [CrossRef]

14. Moreira, K. S.; Moura Júnior, L. S.; Monteiro, R. R. C.; de Oliveira, A. L. B.; Valle, C. P.; Freire, T. M.; Fechine, P. B. A.; de Souza, M. C. M.; Fernandez-Lorente, G.; Guisan, J. M.; dos Santos, J. C. S.; Optimization of the Production of Enzymatic Biodiesel from Residual Babassu Oil (Orbignya sp.) via RSM. Catalysts 2020, 10, 414. [CrossRef]

15. Okoro, O. V.; Sun, Z.; Birch, J.; Em Encyclopedia of Food Chemistry, Melton, L.; Shaidi, F.; Varelis, P. (eds), Academic Press: Amsterdam, 2019, 150. [CrossRef]

16. Bonazza, H. L.; Manzo, R. M.; dos Santos, J. C. S.; Mammarella, E. J.; Operational and Thermal Stability Analysis of Thermomyces lanuginosus Lipase Covalently Immobilized onto Modified Chitosan Supports. Applied Biochemistry and Biotechnology 2018, 184, 182. [CrossRef]

17. Tan, H. W.; Abdul Aziz, A. R.; Aroua, M. K.; Glycerol production and its applications as a raw material: A review. Renewable and Sustainable Energy Reviews 2013, 27, 118. [CrossRef]

18. Christopher, L. P.; Hemanathan Kumar; Zambare, V. P.; Enzymatic biodiesel: Challenges and opportunities. Applied Energy 2014, 119, 497. [CrossRef]

19. Chapman, J.; Ismail, A.; Dinu, C.; Industrial Applications of Enzymes: Recent Advances, Techniques, and Outlooks. Catalysts 2018, 8, 238. [CrossRef]

20. Girelli, A. M.; Salvagni, L.; Tarola, A. M.; Use of lipase immobilized on celluse support for cleaning aged oil layers. Journal of the Brazilian Chemical Society 2012, 23, 585. [CrossRef]

21. Santos, J. C. S. D.; Barbosa, O.; Ortiz, C.; Berenguer-Murcia, A.; Rodrigues, R. C.; Fernandez-Lafuente, R.; Importance of the Support Properties for Immobilization or Purification of Enzymes. ChemCatChem 2015, 7, 2413. [CrossRef]

22. Souza, L. T. A.; Veríssimo, L. A. A.; João, B. C. P.; Santoro, M. M.; Resende, R. R.; Mendes, A. A.; Em Biotecnologia Aplicada à Agro\&Indústria, Vol. 4, Editora Blucher: São Paulo, 2017, 529. [CrossRef]

23. Basso,A.; Serban, S.; Industrial applications of immobilized enzymes-A review. Molecular Catalysis 2019, 479, 110607. [CrossRef]

24. Kim, J.; Grate, J. W.; Wang, P.; Nanostructures for enzyme stabilization. Chemical Engineering Science 2006, 61, 1017. [CrossRef]

25. Jiang, D.; Ni, D.; Rosenkrans, Z. T.; Huang, P.; Yan, X.; Cai, W.; Nanozyme: New horizons for responsive biomedical applications. Chemical Society Reviews 2019, 48, 3683. [CrossRef]

26. Shuai, W.; Das, R. K.; Naghdi, M.; Brar, S. K.; Verma, M.; A review on the important aspects of lipase immobilization on nanomaterials. Biotechnology and Applied Biochemistry 2017, 64, 496. [CrossRef]

27. Begum, S.; Karim, A. N. M.; Ansari, M. N. M.; Hashmi, M. S. J.; Em Encyclopedia of Renewable and Sustainable Material, Hashmi, S.; Choudhury, I. A. (eds), Elsevier: Amsterdam, 2020, 515. [CrossRef] 
28. Macrae, A. R.; Hammond, R. C.; Present and Future Applications of Lipases. Biotechnology and Genetic Engineering Reviews 1985, 3, 193. [CrossRef]

29. Matte, C.; Bordinhão, C.; Poppe, J.; Benvenutti, E.; Costa, T.; Rodrigues, R.; Hertz, P.; Ayub, M.; Physical-Chemical Properties of the Support Immobead 150 Before and After the Immobilization Process of Lipase. Journal of the Brazilian Chemical Society 2016, 28, 1430. [CrossRef]

30. Rueda, N.; Dos Santos, J. C. S.; Torres, R.; Ortiz, C.; Barbosa, O.; Fernandez-Lafuente, R.; Immobilization of Lipases on Heterofunctional Octyl-Glyoxyl Agarose Supports Improved Stability and Prevention of the Enzyme Desorption, 1a. ed, Elsevier: Amsterdam, 2016. [CrossRef]

31. Thakur, S.; Lipases, its sources, properties and applications: A review. International Journal of Scientific \& Engineering Research 2012, 3, 1. [CrossRef]

32. Ortiz, C.; Ferreira, M. L.; Barbosa, O.; dos Santos, J. C. S.; Rodrigues, R. C.; Berenguer-Murcia, Á.; Briand, L. E.; Fernandez-Lafuente, R.; Novozym 435: the "perfect" lipase immobilized biocatalyst?. Catalysis Science \& Technology 2019 , 9, 2380. [CrossRef]

33. Krüger, A.; Schäfers, C.; Schröder, C.; Antranikian, G.; Towards a sustainable biobased industry - Highlighting the impact of extremophiles. New Biotechnology 2018, 40, 144. [CrossRef]

34. Jangale, A. D.; Dalal, D. S.; Green synthetic approaches for biologically relevant organic compounds. Synthetic Communications 2017, 47, 2139. [CrossRef]

35. Mattson, F. H.; Volpenhein, R. A.; Enzymatic hydrolysis at an oil/ water interface. Journal of the American Oil Chemists' Society 1966, 43, 286. [CrossRef]

36. Zaks, A.; Klibanov, A. M.; Enzyme-catalyzed processes in organic solvents. Proceedings of the National Academy of Sciences 1985, 82, 3192. [CrossRef]

37. de Oliveira, U. M. F.; Lima de Matos, L. J. B.; de Souza, M. C. M.; Pinheiro, B. B.; dos Santos, J. C. S.; Gonçalves, L. R. B.; Efficient biotechnological synthesis of flavor esters using a low-cost biocatalyst with immobilized Rhizomucor miehei lipase. Molecular Biology Reports 2019, 46, 597. [CrossRef]

38. Chen, Z.; Huang, S.; Zhao, M.; Em Molecularly Imprinted Catalysts, Elsevier: Amsterdam, 2016. [CrossRef]

39. Liu, J.; Ma, R.-T.; Shi, Y.-P.; Recent advances on support materials for lipase immobilization and applicability as biocatalysts in inhibitors screening methods -A Review. Analytica Chimica Acta 2019, 1101, 9. [CrossRef]

40. Pandey, A.; Benjamin, S.; Soccol, C. R.; Nigam, P.; Krieger, N.; Soccol, V. T.; The realm of microbial lipases in biotechnology. Biotechnology and Applied Biochemistry 1999, 29, 119. [CrossRef]

41. Gupta, R.; Kumari, A.; Syal, P.; Singh, Y.; Molecular and functional diversity of yeast and fungal lipases: Their role in biotechnology and cellular physiology. Progress in Lipid Research 2015, 57, 40. [CrossRef]

42. Messias, J. M.; Costa, B. Z. da; Lima, V. M. G. de; Giese, C.; Dekker, R. F. H.; Barbosa, A. de M.; Lipases microbianas: Produção, propriedades e aplicações biotecnológicas. Semina: Ciências Exatas e Tecnológicas 2011, 32, 213. [CrossRef]
43. Velasco-Lozano, S.; Benítez-Mateos, A. I.; López-Gallego, F.; Co-immobilized Phosphorylated Cofactors and Enzymes as Self-Sufficient Heterogeneous Biocatalysts for Chemical Processes. Angewandte Chemie International Edition 2017, 56, 771. [CrossRef]

44. Siirola, E.; Frank, A.; Grogan, G.; Kroutil, W.; C-C Hydrolases for Biocatalysis. Advanced Synthesis \& Catalysis 2013, 355, 1677. [CrossRef]

45. Rodrigues, R. C.; Virgen-Ortíz, J. J.; dos Santos, J. C. S.; Berenguer-Murcia, Á.; Alcantara, A. R.; Barbosa, O.; Ortiz, C.; Fernandez-Lafuente, R.; Immobilization of lipases on hydrophobic supports: immobilization mechanism, advantages, problems, and solutions. Biotechnology Advances 2019, 37, 746. [CrossRef]

46. Rocha, T. G.; de L. Gomes, P. H.; de Souza, M. C. M.; Monteiro, R. R. C.; dos Santos, J. C. S.; Lipase Cocktail for Optimized Biodiesel Production of Free Fatty Acids from Residual Chicken Oil. Catalysis Letters 2020. [CrossRef]

47. Pereira, E. B.; Zanin, G. M.; Castro, H. F.; Immobilization and catalytic properties of lipase on chitosan for hydrolysis and esterification reactions. Brazilian Journal of Chemical Engineering 2003, 20, 343. [CrossRef]

48. Zhang, D.-H.; Yuwen, L.-X.; Xie, Y.-L.; Li, W.; Li, X.-B.; Improving immobilization of lipase onto magnetic microspheres with moderate hydrophobicity/hydrophilicity. Colloids and Surfaces B: Biointerfaces 2012, 89, 73. [CrossRef]

49. Manoel, E. A.; Ribeiro, M. F. P.; Dos Santos, J. C. S.; Coelho, M. A. Z.; Simas, A. B. C.; Fernandez-Lafuente, R.; Freire, D. M. G.; Accurel MP 1000 as a support for the immobilization of lipase from Burkholderia cepacia: Application to the kinetic resolution of myo-inositol derivatives. Process Biochemistry 2015, 50, 1557. [CrossRef]

50. Khan, F. I.; Lan, D.; Durrani, R.; Huan, W.; Zhao, Z.; Wang, Y.; The Lid Domain in Lipases: Structural and Functional Determinan of Enzymatic Properties. Frontiers in Bioengineering and Biotechnology 2017, 5. [CrossRef]

51. Brzozowski, A. M.; Derewenda, U.; Derewenda, Z. S.; Dodson, G. G.; Lawson, D. M.; Turkenburg, J. P.; Bjorkling, F.; HugeJensen, B.; Patkar, S. A.; Thim, L.; A model for interfacial activation in lipases from the structure of a fungal lipase-inhibitor complex. Nature 1991, 351, 491. [CrossRef]

52. Secundo, F.; Carrea, G.; Tarabiono, C.; Gatti-Lafranconi, P.; Brocca, S.; Lotti, M.; Jaeger, K.-E.; Puls, M.; Eggert, T.; The lid is a structural and functional determinant of lipase activity and selectivity. Journal of Molecular Catalysis B: Enzymatic 2006, 39, 166. [CrossRef]

53. Skjold-Jørgensen, J.; Bhatia, V. K.; Vind, J.; Svendsen, A.; Bjerrum, M. J.; Farrens, D.; The Enzymatic Activity of Lipases Correlates with Polarity-Induced Conformational Changes: A Trp-Induced Quenching Fluorescence Study. Biochemistry 2015 , 54, 4186. [CrossRef]

54. Rana, Q. ul ain; Laiq Ur Rehman, M.; Irfan, M.; Ahmed, S.; Hasan, F.; Shah, A. A.; Khan, S.; Badshah, M.; Lipolytic bacterial strains mediated transesterification of non-edible plant oils for generation of high quality biodiesel. Journal of Bioscience and Bioengineering 2019, 127, 609. [CrossRef] 
55. Deckers, M.; Vanneste, K.; Winand, R.; Keersmaecker, S. C. J. De; Denayer, S.; Heyndrickx, M.; Deforce, D.; Fraiture, M.-A.; Roosens, N. H. C.; Strategy for the identification of micro-organisms producing food and feed products: Bacteria producing food enzymes as study case. Food Chemistry 2020, 305, 125431. [CrossRef]

56. Zheng, C. cai; Wu, J. wei; Jin, Z. hong; Ye, Z. feng; Yang, S.; Sun, Y. qiang; Fei, H.; Exogenous enzymes as functional additives in finfish aquaculture. Aquaculture Nutrition 2020, 26, 213. [CrossRef]

57. Agulló, E.; Rodríguez, M. S.; Ramos, V.; Albertengo, L.; Present and Future Role of Chitin and Chitosan in Food. Macromolecular Bioscience 2003, 3, 521. [CrossRef]

58. Silano, V.; Barat Baviera, J. M.; Bolognesi, C.; Cocconcelli, P. S.; Crebelli, R.; Gott, D. M.; Grob, K.; Lampi, E.; Mortensen, A.; Rivière, G.; Steffensen, I.; Tlustos, C.; Van Loveren, H.; Vernis, L.; Zorn, H.; Glandorf, B.; Herman, L.; Marcon, F.; Penninks, A.; Andryszkiewicz, M.; Arcella, D.; Gomes, A.; Kovalkovičová, N.; Liu, Y.; Maia, J.; Roncancio Peña, C.; Chesson, A.; Safety evaluation of the food enzyme $\alpha$-amylase from Aspergillus oryzae (strain DP-Bzb41). EFSA Journal 2019, 17. [CrossRef]

59. Gil-Rodríguez, A. M.; Beresford, T. P.; Lipase inhibitory activity of skim milk fermented with different strains of lactic acid bacteria. Journal of Functional Foods 2019, 60. [CrossRef]

60. Swaroopa Rani, T.; Nadendla, S. R.; Bardhan, K.; Madhuprakash, J.; Podile, A. R.; Chitosan conjugates, microspheres, and nanoparticles with potential agrochemical activity. In: Prasad, M. N. V. (eds) Agrochemicals Detection, Treatment and Remediatio, Elsevier, 2020, 437. [CrossRef]

61. Kashyap, P. L.; Xiang, X.; Heiden, P.; Chitosan nanoparticle based delivery systems for sustainable agriculture. International Journal of Biological Macromolecules 2015, 77, 36. [CrossRef]

62. Oliveira, H. C.; Gomes, B. C. R.; Pelegrino, M. T.; Seabra, A. B.; Nitric oxide-releasing chitosan nanoparticles alleviate the effects of salt stress in maize plants. Nitric Oxide - Biology and Chemistry 2016, 61, 10. [CrossRef]

63. Rueda, N.; dos Santos, J. C. S.; Ortiz, C.; Torres, R.; Barbosa, O.; Rodrigues, R. C.; Berenguer-Murcia, Á.; Fernandez-Lafuente, R.; Chemical Modification in the Design of Immobilized Enzyme Biocatalysts: Drawbacks and Opportunities. Chemical Record 2016, 16, 1436. [CrossRef]

64. Rueda, N.; Dos Santos, C. S.; Rodriguez, M. D.; Albuquerque, T. L.; Barbosa, O.; Torres, R.; Ortiz, C.; Fernandez-Lafuente, R.; Reversible immobilization of lipases on octyl-glutamic agarose beads: A mixed adsorption that reinforces enzyme immobilization. Journal of Molecular Catalysis B: Enzymatic 2016, 128, 10. [CrossRef]

65. Xie; H.; Enzymatic Production of Biodiesel Using Immobilized Lipase on Core-Shell Structured Fe3O4@MIL-100(Fe) Composites. Catalysts 2019, 9, 850. [CrossRef]

66. Muanruksa, P.; Kaewkannetra, P.; Combination of fatty acids extraction and enzymatic esterification for biodiesel production using sludge palm oil as a low-cost substrate. Renewable Energy 2020, 146, 901. [CrossRef]

67. Shomal, R.; Hisham, H.; Mlhem, A.; Hassan, R.; Al-Zuhair, S.; Simultaneous extraction-reaction process for biodiesel production from microalgae. Energy Reports 2019, 5, 37. [CrossRef]
68. Cavalcanti, E. D. C.; Aguieiras, É. C. G.; da Silva, P. R.; Duarte, J. G.; Cipolatti, E. P.; Fernandez-Lafuente, R.; da Silva, J. A. C.; Freire, D. M. G.; Improved production of biolubricants from soybean oil and different polyols via esterification reaction catalyzed by immobilized lipase from Candida rugosa Fuel 2018, 215, 705. [CrossRef]

69. Torres Júnior, P.; Moreira, C. A. L.; O programa de incentivo às energias renováveis no Brasil (PROINFA) e a sua relação com a sustentabilidade: um estudo sobre a política energética brasileira sob a ótica neoliberal neoextrativista. Brazilian Journal of Development 2020, 6, 15466. [CrossRef]

70. Manoel, E. A.; dos Santos, J. C. S.; Freire, D. M. G.; Rueda, N.; Fernandez-Lafuente, R.; Immobilization of lipases on hydrophobic supports involves the open form of the enzyme. Enzyme and Microbial Technology 2015, 71, 53. [CrossRef]

71. Dos Santos, J. C. S.; Garcia-Galan, C.; Rodrigues, R. C.; De Sant'Ana, H. B.; Gonçalves, L. R. B.; Fernandez-Lafuente, R.; Stabilizing hyperactivated lecitase structures through physical treatment with ionic polymers. Process Biochemistry 2014, 49, 1511. [CrossRef]

72. Sahay, S.; Chouhan, D.; Study on the potential of cold-active lipases from psychrotrophic fungi for detergent formulation. Journal of Genetic Engineering and Biotechnology 2018, 16, 319. [CrossRef]

73. Dowling, M.; US20190159992A1 United States, 2019. [CrossRef]

74. Chiari-Andréo, B. G.; Almeida-Cincotto, M. G. J. de; Oshiro, J. A.; Taniguchi, C. Y. Y.; Chiavacci, L. A.; Isaac, V. L. B.; Em Nanoparticles in Pharmacotherapy, Elsevier, 2019. [CrossRef]

75. Mouad, A. M.; Taupin, D.; Lehr, L.; Yvergnaux, F.; Porto, A. L. M.; Aminolysis of linoleic and salicylic acid derivatives with Candida antarctica lipase B: A solvent-free process to obtain amphiphilic amides for cosmetic application. Journal of Molecular Catalysis B: Enzymatic 2016, 126, 64. [CrossRef]

76. Monteiro, R. R. C.; Virgen-Ortiz, J. J.; Berenguer-Murcia, Á.; da Rocha, T. N.; dos Santos, J. C. S.; Alcántara, A. R.; FernandezLafuente, R.; Biotechnological relevance of the lipase A from Candida antarctica. Catalysis Today 2021, 362, 141. [CrossRef]

77. Cavalcante, F. T. T.; Neto, F. S.; Rafael de Aguiar Falcão, I.; Erick da Silva Souza, J.; de Moura Junior, L. S.; da Silva Sousa, P.; Rocha, T. G.; de Sousa, I. G.; de Lima Gomes, P. H.; de Souza, M. C. M.; dos Santos, J. C. S.; Opportunities for improving biodiesel production via lipase catalysis. Fuel 2020, 119577. [CrossRef]

78. Lima, R. T.; Alves, A. M.; de Paula, A. V.; de Castro, H. F.; Andrade, G. S. S.; Mycelium-bound lipase from Penicillium citrinum as biocatalyst for the hydrolysis of vegetable oils. Biocatalysis and Agricultural Biotechnology 2019, 22, 101410. [CrossRef]

79. Murillo, G.; Ali, S. S.; Sun, J.; Yan, Y.; Bartocci, P.; El-Zawawy, N.; Azab, M.; He, Y.; Fantozzi, F.; Ultrasonic emulsification assisted immobilized Burkholderia cepacia lipase catalyzed transesterification of soybean oil for biodiesel production in a novel reactor design. Renewable Energy 2019, 135, 1025. [CrossRef]

80. Matuoog, N.; Li, K.; Yan, Y.; Immobilization of Thermomyces lanuginosus lipase on multi-walled carbon nanotubes and its application in the hydrolysis of fish oil. Materials Research Express 2017, 4, 125402. [CrossRef] 
81. Melis, S.; Meza Morales, W. R.; Delcour, J. A.; Lipases in wheat flour bread making: Importance of an appropriate balance between wheat endogenous lipids and their enzymatically released hydrolysis products. Food Chemistry 2019, 298, 125002. [CrossRef]

82. De Souza, M. C. M.; Dos Santos, K. P.; Freire, R. M.; Barreto, A. C. H.; Fechine, P. B. A.; Gonçalves, L. R. B.; Production of flavor esters catalyzed by Lipase B from Candida antarctica immobilized on magnetic nanoparticles. Brazilian Journal of Chemical Engineering 2017, 34, 681. [CrossRef]

83. Duan, X.; Xiang, M.; Wang, L.; Yan, Q.; Yang, S.; Jiang, Z.; Biochemical characterization of a novel lipase from Malbranchea cinnamomea suitable for production of lipolyzed milkfat flavor and biodegradation of phthalate esters. Food Chemistr 2019, 297, 124925. [CrossRef]

84. Contesini, F. J.; Calzado, F.; Madeira, J. V.; Rubio, M. V.; Zubieta, M. P.; de Melo, R. R.; Gonçalves, T. A.; Em Fungal Metabolites, Mérillon, J. M., Ramawat, K. (eds), Springer: New York, 2017, cap 5. [CrossRef]

85. Quiñones, J.P.; Peniche,H.; Peniche, C.; Chitosan based self-assembled nanoparticles in drug delivery. Polymers 2018, 10, 1. [CrossRef]

86. Brígida, A. I. S.; Amaral, P. F. F.; Coelho, M. A. Z.; Gonçalves, L. R. B.; Lipase from Yarrowia lipolytica: Production, characterization and application as an industrial biocatalyst. Journal of Molecular Catalysis B: Enzymatic 2014, 101, 148. [CrossRef]

87. de Oliveira, U. M. F.; Lima de Matos, L. J. B.; de Souza, M. C. M.; Pinheiro, B. B.; dos Santos, J. C. S.; Gonçalves, L. R. B.; Effect of the Presence of Surfactants and Immobilization Conditions on Catalysts' Properties of Rhizomucor miehei Lipase onto Chitosan. Applied Biochemistry and Biotechnology 2018, 184, 1263. [CrossRef]

88. Cubides-Roman, D. C.; Pérez, V. H.; de Castro, H. F.; Orrego, C. E.; Giraldo, O. H.; Silveira, E. G.; David, G. F.; Ethyl esters (biodiesel) production by Pseudomonas fluorescens lipase immobilized on chitosan with magnetic properties in a bioreactor assisted by electromagnetic field. Fuel 2017, 196, 481. [CrossRef]

89. Yousefi, M.; Marciello, M.; Guisan, J. M.; Fernandez-Lorente, G.; Mohammadi, M.; Filice, M.; Fine Modulation of the Catalytic Properties of Rhizomucor miehei Lipase Driven by Different Immobilization Strategies for the Selective Hydrolysis of Fish Oil. Molecules 2020, 25, 545. [CrossRef]

90. Zniszczoł, A.; Herman, A. P.; Szymańska, K.; Mrowiec-Białoń, J.; Walczak, K. Z.; Jarzebski, A.; Boncel, S.; Covalently immobilized lipase on aminoalkyl-, carboxy- and hydroxymulti-wall carbon nanotubes in the enantioselective synthesis of Solketal esters. Enzyme and Microbial Technology 2016, 87-88, 61. [CrossRef]

91. Raveendran, S.; Parameswaran, B.; Ummalyma, S. B.; Abraham, A.; Mathew, A. K.; Madhavan, A.; Rebello, S.; Pandey, A.; Applications of Microbial Enzymes in Food Industry. Enzyme and Microbial Technology 2018, 56, 16. [CrossRef]

92. Kosseva, M. R.; Em Food Industry Wastes, Elsevier Inc., 2013, cap 3.

93. Zhang, W. W.; Yang, X. L.; Jia, J. Q.; Wang, N.; Hu, C. L.; Yu, X. Q.; Surfactant-activated magnetic cross-linked enzyme aggregates (magnetic CLEAs) of Thermomyces lanuginosus lipase for biodiesel production. Journal of Molecular Catalysis B: Enzymatic 2015, 115, 83. [CrossRef]
94. Khan, M. F.; Kundu, D.; Hazra, C.; Patra, S.; A strategic approach of enzyme engineering by attribute ranking and enzyme immobilization on zinc oxide nanoparticles to attain thermostability in mesophilic Bacillus subtilis lipase for detergent formulation. International Journal of Biological Macromolecules 2019, 136, 66. [CrossRef]

95. Villalba, M.; Verdasco-Martín, C. M.; dos Santos, J. C. S.; Fernandez-Lafuente, R.; Otero, C.; Operational stabilities of different chemical derivatives of Novozym 435 in an alcoholysis reaction. International Journal of Biological Macromolecules 2016, 90, 35. [CrossRef]

96. Ching-Velasquez, J.; Fernández-Lafuente, R.; Rodrigues, R. C.; Plata, V.; Rosales-Quintero, A.; Torrestiana-Sánchez, B.; TaciasPascacio, V. G.; Production and characterization of biodiesel from oil of fish waste by enzymatic catalysis. Renewable Energy 2020, 153, 1346. [CrossRef]

97. Pandey, A.; Larroche, C.; Dussap, C.-G.; Gnansounou, E.; Khanal, S. K.; Ricke, S.; Em Biomass, Biofuels, Biochemicals, 2nd ed., Academic Press: Amsterdam, 2019, 152. [CrossRef]

98. Cipolatti, E. P.; Valério, A.; Henriques, R. O.; Moritz, D. E.; Ninow, J. L.; Freire, D. M. G.; Manoel, E. A.; Fernandez-Lafuente, R.; De Oliveira, D.; Nanomaterials for biocatalyst immobilization-state of the art and future trends. RSCAdvances 2016, 6, 104675. [CrossRef]

99. Filho, D. G.; Silva, A. G.; Guidini, C. Z.; Lipases: sources, immobilization methods, and industrial applications. Applied Microbiology and Biotechnology 2019, 103, 7399. [CrossRef]

100. Zdarta, J.; Meyer,A. S.; Jesionowski,T.; Pinelo, M.; A general overview of support materials for enzyme immobilization: Characteristics, properties, practical utility. Catalysts 2018, 8 . [CrossRef]

101. Cacicedo, M. L.; Manzo, R. M.; Municoy, S.; Bonazza, H. L.; Islan, G. A.; Desimone, M.; Bellino, M.; Mammarella, E. J.; Castro, G. R.; Immobilized Enzymes and Their Applications. Advances in Enzyme Technology 2019, 169. [CrossRef]

102. Zaitsev, S. Y.; Savina, A. A.; Zaitsev, I. S.; Biochemical aspects of lipase immobilization at polysaccharides for biotechnology. Advances in Colloid and Interface Science 2019, 272, 102016. [CrossRef]

103. Claaßen, C.; Gerlach, T.; Rother, D.; Stimulus-Responsive Regulation of Enzyme Activity for One-Step and Multi-Step Syntheses. Advanced Synthesis \& Catalysis 2019, 2387. [CrossRef]

104. Mateo, C.; Palomo, J. M.; Fernandez-Lorente, G.; Guisan, J. M.; Fernandez-Lafuente, R.; Improvement of enzyme activity, stability and selectivity via immobilization techniques. Enzyme and Microbial Technology 2007, 40, 1451. [CrossRef]

105. Mohamad, N. R.; Marzuki, N. H. C.; Buang, N. A.; Huyop, F.; Wahab, R. A.; An overview of technologies for immobilization of enzymes and surface analysis techniques for immobilized enzymes. Biotechnology \& Biotechnological Equipment $\mathbf{2 0 1 5}$ 29, 205. [CrossRef]

106. Tamer, T.; Omer, A.; Hassan, M.; Methods of Enzyme Immobilization. International Journal of Current Pharmaceutical Review and Research 2016, 7, 385. [CrossRef]

107. Rios, N. S.; Neto, D. M. A.; dos Santos, J. C. S.; Fechine, P. B. A.; Fernández-Lafuente, R.; Gonçalves, L. R. B.; Comparison of the immobilization of lipase from Pseudomonas fluorescens on divinylsulfone or p-benzoquinone activated support International Journal of Biological Macromolecules 2019, 134 936. [CrossRef] 
108. Bosio, V. E.; Islan, G. A.; Martínez, Y. N.; Durán, N.; Castro, G. R.; Nanodevices for the immobilization of therapeutic enzymes. Critical Reviews in Biotechnologyl 2015, 1. [CrossRef]

109. Franssen, M. C. R.; Steunenberg, P.; Scott, E. L.; Zuilhof, H.; Sanders, J. P. M.; Immobilized enzymes in biorenewables production. Chemical Society Reviews. 2013, 42, 6491. [CrossRef]

110. Robinson, P. K.; Enzymes: principles and biotechnological applications. Essays in Biochemistry 2015, 59, 1. [CrossRef]

111. Bayne, L.; Ulijn, R. V.; Halling, P. J.; Effect of pore size on the performance of immobilised enzymes. Chemical Society Reviews 2013, 42, 9000. [CrossRef]

112. Dalla-Vecchia, R.; Nascimento, M. da G.; Soldi, V.; Aplicações sintéticas de lipases imobilizadas em polímeros. Química Nova 2004, 27, 623. [CrossRef]

113.Liu, S. Em Bioprocess Engineering, Elsevier: Amsterdam, 2017, cap 2.

114. Gill, I.; Ballesteros, A.; Bioencapsulation within synthetic polymers (Part 1): sol-gel encapsulated biologicals. Chemical Society Reviews 2000, 18, 282. [CrossRef]

115. Das, S.; Dash, H. R (eds); Handbook of Metal-Microbe Interactions and Bioremediatio, CRC Press: New York, 2017, 837. [CrossRef]

116. Cottone, G.; Giuffrida, S.; Bettati, S.; Bruno, S.; Campanini, B.; Marchetti, M.; Abbruzzetti, S.; Viappiani, C.; Cupane, A.; Mozzarelli, A.; Ronda, L.; More than a Confinement: "Soft" and "Hard" Enzyme Entrapment Modulates Biological Catalyst Function. Catalysts 2019, 9, 1024. [CrossRef]

117. Meryam Sardar, R. A.; Enzyme Immobilization: An Overview on Nanoparticles as Immobilization Matrix. Biochemistry \& Analytical Biochemistry 2015, 04. [CrossRef]

118. Wissam, Z.; Samer, H.; Encapsulation of flaxseed oil extract in alginate-salep system by ionic gelation. Brazilian Journal of Pharmaceutical Science. 2019, 55. [CrossRef]

119. Mandal, S.; Senthil Kumar, S.; Krishnamoorthy, B.; Basu, S. K.; Development and evaluation of calcium alginate beads prepared by sequential and simultaneous methods. Brazilian Journal of Pharmaceutical Science 2010, 46, 785. [CrossRef]

120. Pierre, A. C.; The sol-gel encapsulation of enzymes. Biocatalysis and Biotransformation 2004, 22, 145. [CrossRef]

121. Kaur, K.; Kaushal, P.; Enzymes as Analytical Tools for the Assessment of Food Quality and Food Safety. In: Singh, R. S.; Singhania,R. R.; Pandey, A.; Larroche,C.,(eds) Advances in Enzyme Technology, Elsevier. 2019, 273. [CrossRef]

122. Brena, B.; González-Pombo, P.; Batista-Viera, F.; Immobilization of enzymes: A literature survey. Methods in Molecular Biology 2013, 1051, 15. [CrossRef]

123. Rodrigues, R. C.; Ortiz, C.; Berenguer-Murcia, Á.; Torres, R.; Fernández-Lafuente, R.; Modifying enzyme activity and selectivity by immobilization. Chemical Society Reviews $\mathbf{2 0 1 3}$, 42, 6290. [CrossRef]

124. Nguyen, H. H.; Kim, M.; An Overview of Techniques in Enzyme Immobilization. Applied Science and Convergence Technology 2017, 26, 157. [CrossRef]

125. Rueda, N.; Dos Santos, J. C. S.; Ortiz, C.; Barbosa, O.; FernandezLafuente, R.; Torres, R.; Chemical amination of lipases improves their immobilization on octyl-glyoxyl agarose beads. Catalysis Today 2016, 259, 107. [ [CrossRef]
126. Satar, R.; Jafri, M. A.; Rasool, M.; Ansari, S. A.; Role of Glutaraldehyde in Imparting Stability to Immobilized $\beta$-Galactosidase Systems. Brazilian Archives of Biology and Technology 2018, 60, 1. [CrossRef]

127. Castro, H. F.; Silva, M. L. C. P.; Silva, G. L. J.; Evaluation of inorganic matrixes as supports for immobilization of microbial lipase. Brazilian Journal of Chemical Engineering 2000, 17, 849. [CrossRef]

128. Avhad, M. R.; Marchetti, J. M.; A review on recent advancement in catalytic materials for biodiesel production. Renewable and Sustainable Energy Reviews 2015, 50, 696. [CrossRef]

129. Moazeni, F.; Chen, Y.-C.; Zhang, G.; Enzymatic transesterification for biodiesel production from used cooking oil, a review. Journal of Cleaner Production 2019, 216, 117. [CrossRef]

130. Sheldon, R. A.; van Pelt, S.; Enzyme immobilization in biocatalysis: Why, what and how. Chemical Society Reviews 2013, 42, 6223. [CrossRef]

131. Gupta, M. N.; Kaloti, M.; Kapoor, M.; Solanki, K.; Nanomaterials as Matrices for Enzyme Immobilization. Artiicial Cells, Blood Substitutes, and Biotechnol 2011, 39, 98. [CrossRef]

132. Verma, M. L.; Barrow, C. J.; Puri, M.; Nanobiotechnology as a novel paradigm for enzyme immobilisation and stabilization with potential applications in biodiesel production. Applied Microbiology and Biotechnology 2013, 97, 23. [CrossRef]

133. Bilal, M.; Zhao, Y.; Rasheed, T.; Iqbal, H. M. N.; Magnetic nanoparticles as versatile carriers for enzymes immobilization: A review. International Journal of Biological Macromolecules 2018, 120, 2530. [CrossRef]

134. Mehrasbi, M. R.; Mohammadi, J.; Peyda, M.; Mohammadi, M.; Covalent immobilization of Candida antarctica lipase on coreshell magnetic nanoparticles for production of biodiesel from waste cooking oil. Renewable Energy 2017, 101, 593. [CrossRef]

135. Touqeer, T.; Mumtaz, M. W.; Mukhtar, H.; Irfan, A.; Akram, S.; Shabbir, A.; Rashid, U.; Nehdi, I. A.; Choong, T. S. Y.; Fe3O4PDA-Lipase as Surface Functionalized Nano Biocatalyst for the Production of Biodiesel Using Waste Cooking Oil as Feedstock: Characterization and Process Optimization. Energies 2019, 13, 177. [CrossRef]

136. Falcaro, P.; Ricco, R.; Doherty, C. M.; Liang, K.; Hill, A. J.; Styles, M. J.; MOF positioning technology and device fabrication. Chemical Society Reviews 2014, 43, 5513. [CrossRef]

137. Nadar, S. S.; Rathod, V. K.; Magnetic-metal organic framework (magnetic-MOF): A novel platform for enzyme immobilization and nanozyme applications. International Journal of Biological Macromolecules 2018, 120, 2293. [CrossRef]

138. Chen, M.; Zeng, G.; Xu, P.; Lai, C.; Tang, L.; How do Enzymes 'Meet' Nanoparticles and Nanomaterials?. Trends in Biochemical Sciences 2017, 42, 914. [CrossRef]

139. Ansari, S. A.; Husain, Q.; Potential applications of enzymes immobilized on/in nano materials: A review. Biotechnology Advances 2012, 30, 512. [CrossRef]

140. Meryam Sardar, R. A.; Enzyme Immobilization: An Overview on Nanoparticles as Immobilization Matrix. Biochemistry \& Analytical Biochemistry 2015, 4. [CrossRef] 
141. Sharifi, M.; Sohrabi, M. J.; Hosseinali, S. H.; Hasan, A.; Kani, P. H.; Talaei, A. J.; Karim, A. Y.; Nanakali, N. M. Q.; Salihi, A.; Aziz, F. M.; Yan, B.; Khan, R. H.; Saboury, A. A.; Falahati, M.; Enzyme immobilization onto the nanomaterials: Application in enzyme stability and prodrug-activated cancer therapy. International Journal of Biological Macromolecules 2020, 143, 665. [CrossRef]

142. Monteiro, R. R. C.; Lima, P. J. M.; Pinheiro, B. B.; Freire, T. M.; Dutra, L. M. U.; Fechine, P. B. A.; Gonçalves, L. R. B.; De Souza, M. C. M.; Santos, J. C. S.; Fernandez-Lafuente, R.; Immobilization of Lipase A from Candida antarctica onto Chitosan-Coated Magnetic Nanoparticles. International Journal of Molecular Sciences 2019, 20. [CrossRef]

143. Verma, M. L.; Naebe, M.; Barrow, C. J.; Puri, M.; Enzyme Immobilization on Amino-Functionalised Multi-Walled Carbon Nanotubes: Structural and Biocatalytic Characterisation. PLoS One 2013, 8, e73642. [CrossRef]

144. Carrasco-López, C.; Godoy, C.; de las Rivas, B.; FernándezLorente, G.; Palomo, J. M.; Guisán, J. M.; Fernández-Lafuente, R.; Martínez-Ripoll, M.; Hermoso, J. A.; Activation of Bacterial Thermoalkalophilic Lipases Is Spurred by Dramatic Structural Rearrangements. Journal of Biological Chemistry 2009, 284, 4365. [CrossRef]

145. Verger, R.; 'Interfacial activation' of lipases: facts and artifacts. Trends in Biotechnology 1997, 15, 32. [CrossRef]

146. Bosley, J. A.; Peilow, A. D.; Immobilization of Lipases for use in Non-Aqueous Reaction Systems. In: Gupta M.N. (eds) Methods in Non-Aqueous Enzymology Birkhäuser, Basel. 2000, 62. [CrossRef]

147. Xu, W.; Ling, P.; Zhang, T.; Polymeric Micelles, a Promising Drug Delivery System to Enhance Bioavailability of Poorly Water-Soluble Drugs. Journal of Drug Delivery 2013, 2013, 1. [CrossRef]

148. Rios, N. S.; Morais, E. G.; dos Santos Galvão, W.; Andrade Neto, D. M.; dos Santos, J. C. S.; Bohn, F.; Correa, M. A.; Fechine, P. B. A.; Fernandez-Lafuente, R.; Gonçalves, L. R. B.; Further stabilization of lipase from Pseudomonas fluorescens immobilized on octyl coated nanoparticles via chemical modification with bifunctional agents. International Journal of Biological Macromolecules 2019, 141, 313. [CrossRef]

149. Giannakopoulou, A.; Gkantzou, E.; Polydera, A.; Stamatis, H.; Multienzymatic Nanoassemblies: Recent Progress and Applications. Trends in Biotechnology 2020, 38, 202. [CrossRef]

150. Alves, J. S.; Vieira, N. S.; Cunha, A. S.; Silva, A. M.; Záchia Ayub, M. A.; Fernandez-Lafuente, R.; Rodrigues, R. C.; Combi-lipase for heterogeneous substrates: a new approach for hydrolysis of soybean oil using mixtures of biocatalysts. RSC Advances 2014, 4, 6863. [CrossRef]

151. Poppe, J. K.; Matte, C. R.; Peralba, M. do C. R.; FernandezLafuente, R.; Rodrigues, R. C.; Ayub, M. A. Z.; Optimization of ethyl ester production from olive and palm oils using mixtures of immobilized lipases. Applied Catalysis A: General 2015, 490, 50. [CrossRef]

152. Toro, E. C.; Rodríguez, D. F.; Morales, N.; García, L. M.; Godoy, C. A.; Novel Combi-lipase Systems for Fatty Acid Ethyl Esters Production. Catalysts 2019, 9, 546. [CrossRef]
153. Angajala, G.; Pavan, P.; Subashini, R.; Lipases: An overview of its current challenges and prospectives in the revolution of biocatalysis. Biocatalysis and Agricultural Biotechnology 2016, 7, 257. [CrossRef]

154. de Vasconcellos, A.; Miller, A. H.; Aranda, D. A. G.; Nery, J. G.; Biocatalysts based on nanozeolite-enzyme complexes: Effects of alkoxysilane surface functionalization and biofuel production using microalgae lipids feedstock. Colloids and Surfaces B: Biointerfaces 2018, 165, 150. [CrossRef]

155. Hama, S.; Noda, H.; Kondo, A.; How lipase technology contributes to evolution of biodiesel production using multiple feedstocks. Current Opinion in Biotechnology 2018, 50, 57. [CrossRef]

156. Singh, D.; Sharma, D.; Soni, S. L.; Sharma, S.; Kumar Sharma, P.; Jhalani, A.; A review on feedstocks, production processes, and yield for different generations of biodiesel. Fuel 2020, 262, 116553. [CrossRef]

157. Zhang, X. L.; Yan, S.; Tyagi, R. D.; Surampalli, R. Y.; Biodiesel production from heterotrophic microalgae through transesterification and nanotechnology application in the production. Renewable and Sustainable Energy Reviews 2013, 26, 216. [CrossRef]

158. Biswas, A.; Em Sustainable Approaches for Biofuels Production Technologies. Biofuel and Biorefinery Technologies, vol 7, Srivastava, N.; Srivastava, M.; Mishra, P. K.; Upadhyay, S. N.; Ramteke, P. W.; Gupta, V. K., (eds), Springer: New York, 2019, cap. 10. [CrossRef]

159. Ahmadi, M. H.; Ghazvini, M.; Alhuyi Nazari, M.; Ahmadi, M. A.; Pourfayaz, F.; Lorenzini, G.; Ming, T.; Renewable energy harvesting with the application of nanotechnology: A review. International Journal of Energy Research 2019, 43, 1387. [CrossRef]

160. Sekoai, P. T.; Ouma, C. N. M.; du Preez, S. P.; Modisha, P.; Engelbrecht, N.; Bessarabov, D. G.; Ghimire, A.; Application of nanoparticles in biofuels: An overview. Fuel 2019, 237, 380. [CrossRef]

161. Noraini, M. Y.; Chyuan, H.; Jan, M.; Chong, W. T.; A review on potential enzymatic reaction for biofuel production from algae. Renewable and Sustainable Energy Reviews 2014, 39, 24. [CrossRef]

162. Rosha, P.; Mohapatra, S. K.; Mahla, S. K.; Cho, H.; Chauhan, B. S.; Dhir, A.; Effect of compression ratio on combustion, performance, and emission characteristics of compression ignition engine fueled with palm (B20) biodiesel blend. Energy 2019, 178, 676. [CrossRef]

163. Fingerman, K. R.; Sheppard, C.; Harris, A.; California's Low Carbon Fuel Standard: Modeling financial least-cost pathways to compliance in Northwest California. Transportation Research Part D: Transport and Environment 2018, 63, 320. [CrossRef]

164. Banerjee, S.; Rout, S.; Banerjee, S.; Atta, A.; Das, D.; Fe2O3 nanocatalyst aided transesterification for biodiesel production from lipid-intact wet microalgal biomass: A biorefinery approach. Energy Conversion and Management 2019, 195, 844. [CrossRef]

165. Xie, W.; Ma, N.; Immobilized Lipase on Fe3O4 Nanoparticles as Biocatalyst for Biodiesel Production. Energy \& Fuels 2009, 23, 1347. [CrossRef] 
166. Sakai, S.; Liu, Y.; Yamaguchi, T.; Watanabe, R.; Kawabe, M.; Kawakami, K.; Production of butyl-biodiesel using lipase physically-adsorbed onto electrospun polyacrylonitrile fibers. Bioresource Technology 2010, 101, 7344. [CrossRef]

167. Li, S.-F.; Fan, Y.-H.; Hu, R.-F.; Wu, W.-T.; Pseudomonas cepacia lipase immobilized onto the electrospun PAN nanofibrous membranes for biodiesel production from soybean oil. Journal of Molecular Catalysis B: Enzymatic 2011, 72, 40. [CrossRef]

168. Wang, X.; Liu, X.; Zhao, C.; Ding, Y.; Xu, P.; Biodiesel production in packed-bed reactors using lipase-nanoparticle biocomposite. Bioresource Technology 2011, 102, 6352. [CrossRef]

169. Tran, D.-T.; Chen, C.-L.; Chang, J.-S.; Immobilization of Burkholderia sp. lipase on a ferric silica nanocomposite for biodiesel production. Journal of Biotechnology 2012, 158, 112. [CrossRef]

170. Ngo, T. P. N.; Li, A.; Tiew, K. W.; Li, Z.; Efficient transformation of grease to biodiesel using highly active and easily recyclable magnetic nanobiocatalyst aggregates. Bioresource Technology 2013, 145, 233. [CrossRef]

171. Tran, D. T.; Chen, C. L.; Chang, J. S.; Effect of solvents and oil content on direct transesterification of wet oil-bearing microalgal biomass of Chlorella vulgaris ESP-31 for biodiesel synthesis using immobilized lipase as the biocatalyst. Bioresource Technology. 2013, 135, 213. [CrossRef]

172. Deep, A.; Sharma, A. L.; Kumar, P.; Lipase immobilized carbon nanotubes for conversion of Jatropha oil to fatty acid methyl esters. Biomass and Bioenergy 2015, 81, 83. [CrossRef]

173. Raita, M.; Arnthong, J.; Champreda, V.; Laosiripojana, N.; Modification of magnetic nanoparticle lipase designs for biodiesel production from palm oil. Fuel Processing Technology 2015, 134, 189. [CrossRef]

174. Andrade, M. F. C.; Parussulo, A. L. A.; Netto, C. G. C. M.; Andrade, L. H.; Toma, H. E.; Lipase immobilized on polydopamine-coated magnetite nanoparticles for biodiesel production from soybean oil. Biofuel Research Journal 2016, 3, 403. [CrossRef]

175. Babaki, M.; Yousefi, M.; Habibi, Z.; Mohammadi, M.; Yousefi, P.; Mohammadi, J.; Brask, J.; Enzymatic production of biodiesel using lipases immobilized on silica nanoparticles as highly reusable biocatalysts: Effect of water, t-butanol and blue silica gel contents. Renewable Energy 2016, 91, 196. [CrossRef]

176. Mukherjee, J.; Gupta, M. N.; Lipase coated clusters of iron oxide nanoparticles for biodiesel synthesis in a solvent free medium. Bioresource Technology 2016, 209, 166. [CrossRef]

177. Karimi, M.; Immobilization of lipase onto mesoporous magnetic nanoparticles for enzymatic synthesis of biodiesel. Biocatal. Agric. Biotechnol 2016, 8, 182. [CrossRef]

178. Tran, D. T.; Chen, C. L.; Chang, J. S.; Continuous biodiesel conversion via enzymatic transesterification catalyzed by immobilized Burkholderia lipase in a packed-bed bioreactor. Applied Energy 2016, 168, 340. [CrossRef]

179. Zhang, Q.; Zheng, Z.; Liu, C.; Liu, C.; Tan, T.; Biodiesel production using lipase immobilized on epoxychloropropanemodified Fe3O4 sub-microspheres. Colloids and Surfaces B: Biointerfaces 2016, 140, 446. [CrossRef]
180. Fan, Y.; Su, F.; Li, K.; Ke, C.; Yan, Y.; Carbon nanotube filled with magnetic iron oxide and modified with polyamidoamine dendrimers for immobilizing lipase toward application in biodiesel production. Scientific Reports 2017, 7, 45643. [CrossRef]

181. Miao, C.; Yang, L.; Wang, Z.; Luo, W.; Li, H.; Lv, P.; Yuan, Z.; Lipase immobilization on amino-silane modified superparamagnetic $\mathrm{Fe} 3 \mathrm{O} 4$ nanoparticles as biocatalyst for biodiesel production. Fuel 2018, 224, 774. [CrossRef]

182. Sharma, R. K.; O’Neill, C. A.; Ramos, H. A. R.; Thapa, B.; BarceloBovea, V. C.; Gaur, K.; Griebenow, K.; Candida rugosa lipase nanoparticles as robust catalyst for biodiesel production in organic solvents. Biofuel Research Journal 2019, 6, 1025. [CrossRef]

183. Thangaraj, B.; Jia, Z.; Dai, L.; Liu, D.; Du, W.; Effect of silica coating on $\mathrm{Fe} 3 \mathrm{O} 4$ magnetic nanoparticles for lipase immobilization and their application for biodiesel production. Arabian Journal of Chemistry 2019, 12, 4694. [CrossRef]

184. Mohammadi, F.; Rahimi, M.; Parvareh, A.; Feyzi, M.; Stimulation of magnetic nanoparticles to intensify transesterification of soybean oil in micromixers for biodiesel production. Chemical Engineering and Processing: Process Intensification 2017, 122, 109. [CrossRef]

185. Dhawane, S. H.; Kumar, T.; Halder, G.; Recent advancement and prospective of heterogeneous carbonaceous catalysts in chemical and enzymatic transformation of biodiesel. Energy Conversion and Management 2018, 167, 176. [CrossRef]

186. Chen, Y.-H.; Huang, Y.-H.; Lin, R.-H.; Shang, N.-C.; A continuous-flow biodiesel production process using a rotating packed bed. Bioresource Technology 2010, 101, 668. [CrossRef]

187. Natarajan, Y.; Nabera, A.; Salike, S.; Dhanalakshmi Tamilkkuricil, V.; Pandian, S.; Karuppan, M.; Appusamy, A.; An overview on the process intensification of microchannel reactors for biodiesel production. Chemical Engineering and Processing - Process Intensification 2019, 136, 163. [CrossRef]

188. Tiwari, A.; Rajesh, V. M.; Yadav, S.; Biodiesel production in micro-reactors: A review. Energy for Sustainable Development 2018, 43, 143. [CrossRef]

189. Oh, Y.-K.; Hwang, K.-R.; Kim, C.; Kim, J. R.; Lee, J.-S.; Recent developments and key barriers to advanced biofuels: A short review. Bioresource Technology 2018, 257, 320. [CrossRef]

190. Verma, M. L.; Puri, M.; Barrow, C. J.; Recent trends in nanomaterials immobilised enzymes for biofuel production. Critical Reviews in Biotechnology 2016, 36, 108. [CrossRef]

191. Aguieiras, E. C. G.; de Barros, D. S. N.; Fernandez-Lafuente, R.; Freire, D. M. G.; Production of lipases in cottonseed meal and application of the fermented solid as biocatalyst in esterification and transesterification reactions. Renewable Energy 2019, 130, 574. [CrossRef]

192. Chojnacka, A.; Gładkowski, W.; Production of Structured Phosphatidylcholine with High Content of Myristic Acid by Lipase-Catalyzed Acidolysis and Interesterification. Catalysts 2018, 8, 281. [CrossRef]

193. Choi, N.; No, D. S.; Kim, H.; Kim, B. H.; Kwak, J.; Lee, J.-S.; Kim, I.-H.; In situ lipase-catalyzed transesterification in rice bran for synthesis of fatty acid methyl ester. Industrial Crops and Products 2018, 120, 140. [CrossRef] 
194. de Souza, T. C.; de Sousa Fonseca, T.; de Sousa Silva, J.; Lima, P. J. M.; Neto, C. A. C. G.; Monteiro, R. R. C.; Rocha, M. V. P.; de Mattos, M. C.; dos Santos, J. C. S.; Gonçalves, L. R. B.; Modulation of lipase B from Candida antarctica properties via covalent immobilization on eco-friendly support for enzymatic kinetic resolution of rac-indanyl acetate. Bioprocess and Biosystems Engineering 2020, 43, 2253. [CrossRef]

195. Carneiro, E.; Bastos, A.; de Oliveira, U.; de Matos, L.; Adriano, W.; Monteiro, R.; dos Santos, J.; Gonçalves, L.; Improving the catalytic features of the lipase from Rhizomucor miehei immobilized on Chitosan-based hybrid matrices by altering the chemical activation conditions. Química Nova 2020, 43. [CrossRef]

196. Bezerra, R. M.; Monteiro, R. R. C.; Neto, D. M. A.; da Silva, F. F. M.; de Paula, R. C. M.; de Lemos, T. L. G.; Fechine, P. B. A.; Correa, M. A.; Bohn, F.; Gonçalves, L. R. B.; dos Santos, J. C. S.; A new heterofunctional support for enzyme immobilization: PEI functionalized $\mathrm{Fe} 3 \mathrm{O} 4 \mathrm{MNPs}$ activated with divinyl sulfone. Application in the immobilization of lipase from Thermomyces lanuginosus. Enzyme and Microbial Technology 2020, 138, 109560. [CrossRef]

197. Moreira, K. da S.; de Oliveira, A. L. B.; Júnior, L. S. de M.; Monteiro, R. R. C.; da Rocha, T. N.; Menezes, F. L.; Fechine, L. M. U. D.; Denardin, J. C.; Michea, S.; Freire, R. M.; Fechine, P. B. A.; Souza, M. C. M.; dos Santos, J. C. S.; Lipase From Rhizomисor miehei Immobilized on Magnetic Nanoparticles: Performance in Fatty Acid Ethyl Ester (FAEE) Optimized Production by the Taguchi Method. Frontiers in Bioengineering and Biotechnology 2020, 8, 693. [CrossRef]

198. Pinheiro, M. P.; Monteiro, R. R. C.; Silva, F. F. M.; Lemos, T. L. G.; Fernandez-Lafuente, R.; Gonçalves, L. R. B.; dos Santos, J. C. S.; Modulation of Lecitase properties via immobilization on differently activated Immobead-350: Stabilization and inversion of enantiospecificity. Process Biochemistry 2019, 87, 128. [CrossRef]

199. Fonseca, A. M. da; Cleiton Sousa dos Santos, J.; de Souza, M. C. M.; de Oliveira, M. M.; Colares, R. P.; de Lemos, T. L. G.; Braz-Filho, R.; The use of new hydrogel microcapsules in coconut juice as biocatalyst system for the reaction of quinine. Industrial Crops and Products 2020, 145, 111890. [CrossRef]
200. Hwang, E. T.; Lee, S.; Multienzymatic Cascade Reactions via Enzyme Complex by Immobilization. ACS Catalysis 2019, 9 , 4402. [CrossRef]

201. Hermanová, S.; Zarevúcká, M.; Bouša, D.; Pumera, M.; Sofer Z. Graphene oxide immobilized enzymes show high thermal and solvent stability. Nanoscale 2015, 7, 5852. [CrossRef]

202. Srivastava, N.; Srivastava, M.; Mishra, P. K.; Ramteke, P. W.; Application of $\mathrm{ZnO}$ Nanoparticles for Improving the Thermal and $\mathrm{pH}$ Stability of Crude Cellulase Obtained from Aspergillus fumigatus AA001. Frontiers in Microbiology 2016, 7. [CrossRef]

203. Nguyen, M. K.; Moon, J.-Y.; Bui, V. K. H.; Oh, Y.-K.; Lee, Y.C.;Recent advanced applications of nanomaterials in microalgae biorefinery. Algal Research 2019, 41, 101522. [CrossRef]

204. Zeng, L.; He, Y.; Jiao, L.; Li, K.; Yan, Y.; Preparation of Biodiesel with Liquid Synergetic Lipases from Rapeseed Oil Deodorizer Distillate. Applied Biochemistry and Biotechnology 2017, 183, 778. [CrossRef]

205. Filice, M.; Palomo, J. M.; Cascade Reactions Catalyzed by Bionanostructures. ACS Catalysis 2014, 4, 1588. [CrossRef]

206. Akubude, V. C.; Nwaigwe, K. N.; Dintwa, E.; Production of biodiesel from microalgae via nanocatalyzed transesterification process: A review. Materials Science for Energy Technologies 2019, 2, 216. [CrossRef]

207. Nizami, A.-S.; Rehan, M.; Towards nanotechnology-based biofuel industry. Biofuel Research Journal 2018, 5, 798. [CrossRef]

208. Tyagi, S.; Rawtani, D.; Khatri, N.; Tharmavaram, M.; Strategies for Nitrate removal from aqueous environment using Nanotechnology: A Review. Journal of Water Process Engineering 2018, 21, 84. [CrossRef]

209. Madhavan, A.; Sindhu, R.; Binod, P.; Sukumaran, R. K.; Pandey, A.; Strategies for design of improved biocatalysts for industrial applications. Bioresource Technology 2017, 245, 1304 [CrossRef]

210. Wu, S.; Snajdrova, R.; Moore, J. C.; Baldenius, K.; Bornscheuer U. T.; Biocatalysis: Enzymatic Synthesis for Industrial Applications. Angewandte Chemie International Edition 2020, 59, 2. [CrossRef] 